\title{
Review: Analysis of the process and drivers for cellular meat production
}

\author{
R. D. Warner ${ }^{\dagger}$ ๑ \\ School of Agriculture and Food, Faculty of Veterinary and Agricultural Sciences, Parkville, Victoria 3052, Australia
}

(Received 14 May 2019; Accepted 19 July 2019; First published online 28 August 2019)

Cell-based meat, also called 'clean', lab, synthetic or in vitro meat, has attracted much media interest recently. Consumer demand for cellular meat production derives principally from concerns over environment and animal welfare, while secondary considerations include consumer and public health aspects of animal production, and food security. The present limitations to cellular meat production include the identification of immortal cell lines, availability of cost-effective, bovine-serum-free growth medium for cell proliferation and maturation, scaffold materials for cell growth, scaling up to an industrial level, regulatory and labelling issues and at what stage mixing of myo-, adipo- and even fibrocytes can potentially occur. Consumer perceptions that cell-based meat production will result in improvements to animal welfare and the environment have been challenged, with the outcome needing to wait until the processes used in cell-based meat are close to a commercial reality. Challenges for cell-based meat products include the simulation of nutritional attributes, texture, flavour and mouthfeel of animal-derived meat products. There is some question over whether consumers will accept the technology, but likely there will be acceptance of cell-based meat products, in particular market segments. Currently, the cost of growth media, industry scale-up of specific components of the cell culture process, intellectual property sharing issues and regulatory hurdles mean that it will likely require an extended period for cellular meat to be consistently available in high-end restaurants and even longer to be available for the mass market. The progress in plant-based meat analogues is already well achieved, with products such as the Impossible ${ }^{T M}$ Burger and other products already available. These developments may make the development of cellular meat products obsolete. But the challenges remain of mimicking not only the nutritional attributes, flavour, shape and structure of real meat, but also the changes in regulation and labelling.

Keywords: lab meat, environment, health, consumer, animal welfare

\section{Implications}

Cell-based meat, also called 'clean', lab, synthetic or in vitro meat, has attracted much interest from the media recently. The drivers for cell-based meat production include food security, environment and sustainability, consumer and public health/ safety and animal welfare problems associated with meat production, but not all of these challenges will be met by a move to industrial scale cell-based meat. This review discusses the process of cell-based meat production and summarises the significant challenges for the appearance on retail shelves.

\section{Introduction}

The provision of safe, affordable protein is critical to human nutrition and food security (Waughray, 2018). Protein,

\footnotetext{
† E-mail: robyn.warner@unimelb.edu.au
}

particularly from animal-sources, has been shown to play a key role in brain development and function in all humans, particularly in the elderly and in children (Mann, 2018). Although many vegetarian protein sources are available as alternatives, meat continues to be very attractive to most consumers (Van Der Weele and Tramper 2014; Piazza et al., 2015).

As a global community, the drivers for the agriculture and processing industry are focused on food security. Figure 1 shows the projected increase in meat production required for the major meat-producing species by 2050 (FAO, 2012). For these reasons, there has been serious consideration of, and advances in, the production of some nutrients from cellular agriculture. At a consumer level, the proponents of cellular meat have focused their communication strategy around the societies' present concerns around meat consumption, including environmental issues, animal welfare, safety and health (Hocquette, 2016). The increase in urbanisation of human beings and associated loss of connection to 


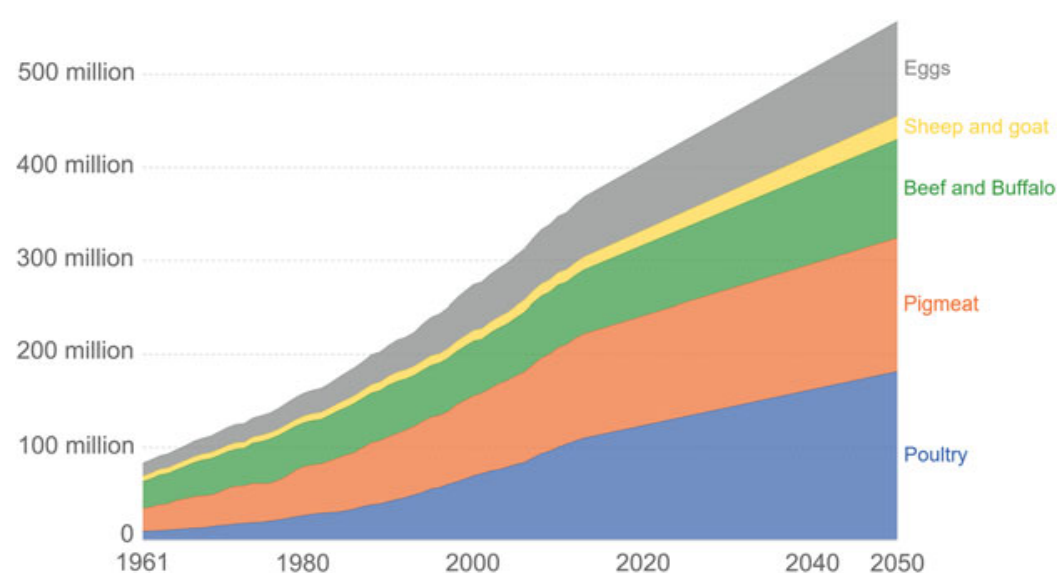

Figure 1 (Colour online) Global meat production (tonnes), based on future population projections and expected impacts of regional and national economic growth trends on meat consumption. Data from 1961 to 2013 are based on published FAO estimates and from 2013 to 2050 are based on FAO projections. Graph from https://www.3fbio.com/hello-world/, with permission, who used data from FAO (2012).

the farm, and how meat is produced, has also led to some consumers' lack of understanding and acceptance of meat production on farms.

This review focuses on the production of meat protein from muscle cells. Reducing the environmental impacts of meat production, and particularly greenhouse gas (GHG) emissions, is potentially a significant potential advantage of cultured meat, but reducing the need for animals in meat production is also an important facet of cell-based meat production, particularly for some urban consumers who are concerned about animal welfare (Tuomisto and Teixeira de Mattos, 2011; Post, 2012).

This review describes the process of cellular meat production, including the challenges and constraints. The drivers for cellular meat production are also presented and analysed, and the future is discussed.

\section{Definition and process of cellular meat production}

The definition of cellular meat production is meat made from stem cells, which tries to mimic traditional meat (Hocquette, 2015). It is essentially a 'substitute for meat made from animals'. The common terms used for this type of meat production include lab meat, cultured meat, in vitro meat, artificial meat, synthetic meat and for those keen to promote the industry, 'clean meat'. Nomenclature for cell-based meat is widely debated, and for an excellent discussion on the various terms and their history and socio-political connotations, see Stephens et al. (2019). Producers, investors and advocates of cell-based meat production prefer to use the term 'clean meat' in order to promote consumer acceptance as it has positive connotations (Bryant and Barnett, 2019). Conversely, those arguing against the term 'clean' meat point out that the term implies that conventional meat production is 'dirty'. The term cell-based meat has been selected for use throughout this article due to the linkage with cellular agriculture, although it is recognised that company marketing and brands will choose different nomenclature, which may be dictated by regulators.
The development of cellular meat production from cells involves a number of biological principles regarding how muscle cells are made in vivo. Replicating these processes at an industrial scale presents a number of technical challenges (Hocquette, 2016). Hence the development of novel meat and protein products is utilising ground-breaking technologies designed to meet the issues facing the conventional meat industry (Bonny et al., 2017).

Muscle comprises muscle cells (myocytes), fat cells (adipocytes), connective tissue cells (fibroblasts) and vascular tissue (endothelial cells). Extensive research has been conducted on conditions for allowing muscle, fat and connective tissue cell culture in vitro, but the aims of these studies have been very diverse. Due to the complexity of conditions involved for culture of each individual cell type, successful and continued co-culture of these cells has not yet been achieved. Different cell types, particularly stem cells, can be used as a source of material to generate cellular meat, and the following section focuses on muscle cell production. The general stages of development of a mature muscle fibre, from a stem cell, including the growth factors required are shown in Figure 2 . The stages of production of meat cells, including the critical decision points, are shown in Figure 3.

\section{Source of cells}

In order to manufacture cellular meat, cells with a large capacity for multiplication must be identified and sourced. Ideally these cells have a self-renewing capacity and can infinitely continue to divide, wherein lies the first challenge (see decision point 1 in Figure 3). Myogenesis starts after the formation of the embryo, continues through the life of the foetus and is mostly completed at birth (Orzechowski, 2015). At birth, all muscle cells (fibres) in the muscle tissue are fully formed and mature, with the main changes during growth and maturation of the animal being changes in muscle cell width (hypertrophy) and some changes in muscle fibre type. Muscle fibres are multinucleate, being a result of fusion of myoblasts which are uninucleate. In animal skeletal muscle tissue, myosatellite stem cells lie just outside the muscle cell, 


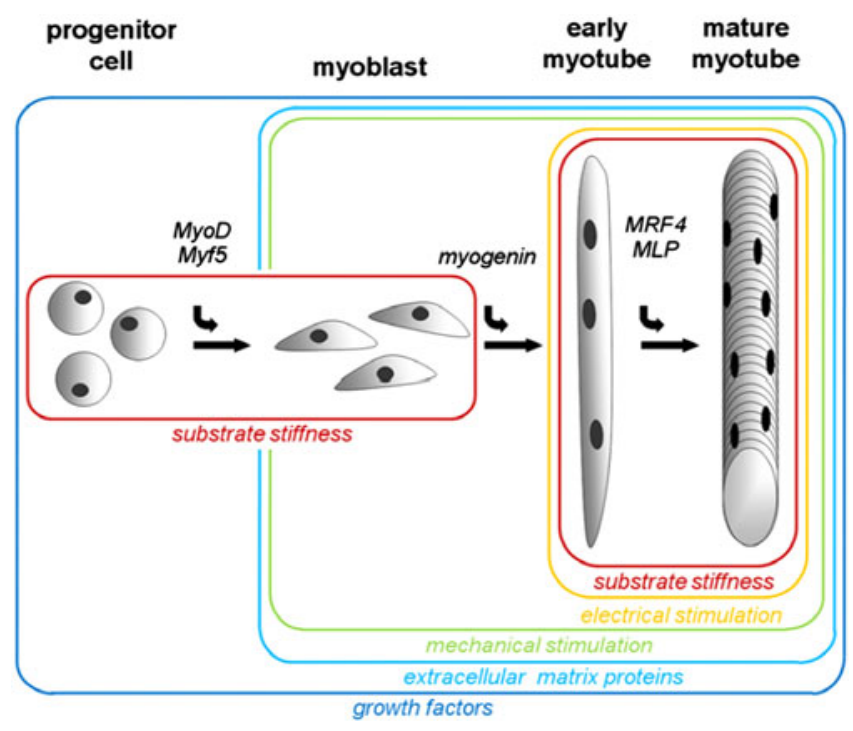

Figure 2 (Colour online) Factors affecting muscle cell proliferation, differentiation and maturation. Substrate stiffness is involved in both the proliferation of myosatellite cells and the maturation of myotubes, whereas mechanical stimulation is important for alignment of myoblasts and maturation of myotubes. Extracellular matrix proteins and growth factors are involved in both differentiation and maturation. Note the myogenic regulatory growth factors indicated at each stage being MyoD (myoblast determination protein 1), Myf5 (myogenic factor 5), myogenin (MyoG, myogenic factor 4), MRF4 (mygenic factor 6 or herculin) and MLP (muscle LIM protein). Source: From Langelaan et al. (2010).

between the sarcolemma and the basement membrane and are usually in a quiescent state (non-dividing) (Datar and Betti, 2010). When stimulated, for example, when muscle cell damage occurs, these satellite cells can divide and provide new nuclei. These new nuclei, once formed, then are transferred from extracellular, to intracellular within the muscle cell. The majority of myogenesis occurs during the development of the embryo and foetus, but myogenesis can also occur through recruitment of myosatellite cells for muscle regeneration after injury or as an adaptation to workload (Orzechowski, 2015). As an organism ages, the regenerative potential of the myosatellite population rapidly decreases, hence the preference for harvesting myosatellite cells from neonate animals (Datar and Betti, 2010).

A stem cell has a unique ability to develop into many different cell types in the body, and all stem cells can selfrenew (make copies of themselves through division) and differentiate (develop into more specialised cells). Stem cells vary widely in what they can and cannot do, and in the circumstances in which they can, and cannot, do certain things. Different types of stem cells, depending on their derivation, have differing longevity and persistency in terms of number of replications in vivo (Kadim et al., 2015). The longevity and derivation are of key importance in muscle cell culture, as a short-lived source of stem cells needs to be constantly replenished with new tissue from a living animal. The four types of stem cells relevant to this article are embryonic, tissuespecific, induced pluripotent and myosatellite. Embryonic stem cells are obtained from the inner call mass of the blastocyst that forms 3 to 5 days after an egg is fertilised by sperm. Embryonic stem cells are pluripotent (can give rise to every cell type in a fully formed body), have long-term persistency, and their number of divisions may be limitless (Kadim et al., 2015). Tissue-specific stem cells, also called adult stem cells, can generate cell types specific to the tissue from which they are derived, and divisions are usually limited to 50 to 60 (see Kadim et al. (2015) for more detailed description). Induced pluripotent stem cells are cells that have been engineered in the laboratory (in vitro) to behave 'like' embryonic stem cells. These have variable, and often unknown, persistence and number of replications. Muscle tissue removed by biopsy from a living mammal can be used to derive 'myosatelite stem cells', which can only differentiate into a muscle cell. For myosatelite stem cells derived from adult animals, the number of divisions can be as low as 20 in vitro (Mouly et al., 2005).

The most promising cell type for cellular meat production is the myosatellite cell, as these are the primary adult stem cell for muscle, although the isolation, culturing and maintenance of a high-quality population of myosatellite cells in vivo is challenging (Post, 2012). Embryonic stem cells would be an ideal starting source for cellular meat production due to the pluripotent nature, but the proliferation and differentiation can be difficult (Kadim et al., 2015). Mosa Meat in the Netherlands (https://www.mosameat.com/) harvests muscle tissue from a living cow with a biopsy, deriving adult myosatellite stem cells whereas in Israel, BioFood Systems (https://www.biofood-systems.com/) wants to produce beef products using bovine embryonic stem cells.

\section{Growth media for proliferation, merging and maturation} Growth of the cells in culture requires nutrients, similar to cells in living tissue. In the absence of a blood supply providing nutrients (and removing waste), cells are bathed in a culture media which provides the important nutrients and growth factors. The growth factors required for proliferation, differentiation and maturation are usually provided by adding $10 \%$ to $20 \%$ growth media (Stephens et al., 2018). The nutrients required, such as carbohydrates, lipids, amino acids and vitamins, are relatively straightforward to predict and calculate, but different growth factors (and hormones) are required at different stages, as shown in Figure 2. This is the second series of challenges and decision points in cellular meat production, being how to supply the right growth media for each stage (decision point 2 in Figure 3).

The culture media needs to be formulated to ensure high rates of cell growth with not only the appropriate level of nutrients, but also the appropriate myogenic regulatory growth factors (myoblast determination protein 1 (MyoD), myogenic factor 5 (Myf5), myogenin factor 4 (MYOG), myogenic factor 6 (MRF4) and muscle LIM protein (MLP); see Figure 2) and hormones (insulin, thyroid hormone, growth hormone). A description of the requirements for growth factors and hormones at different stages for muscle cells from different species is given in Burton et al. (2000). All of these are necessary to culture the cells and to allow them 


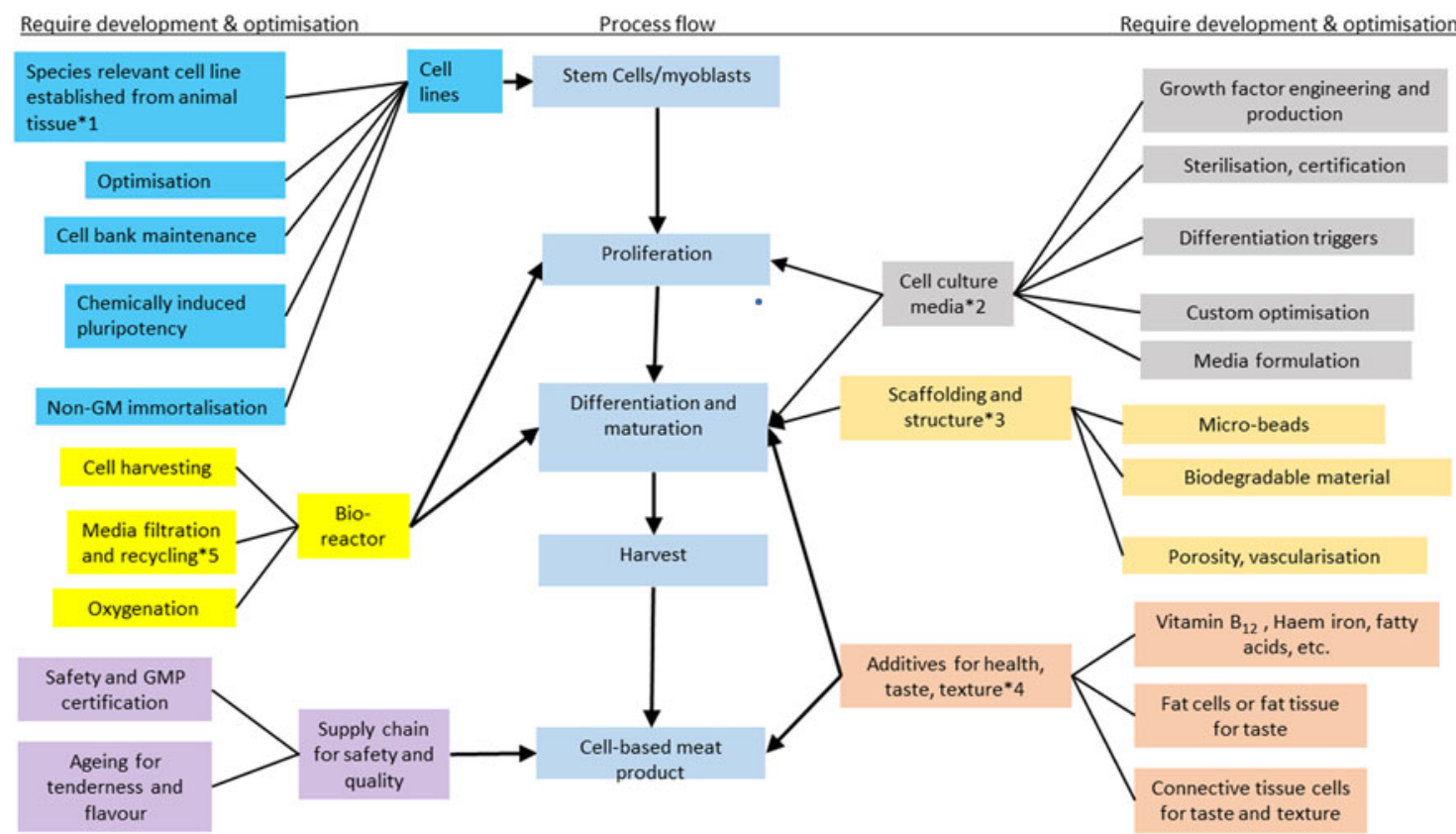

Figure 3 (Colour online) Diagram showing the stages of cellular meat production including the process flow (blue boxes in the centre), the components requiring research, development and optimisation on the extreme left and right and the critical decision points marked by an asterisk (*). Choices which are important decision points for both small scale and industrial production include: (1) source of tissue to derive cells from, (2) growth media to stimulate differentiation, proliferation, formation of myotubes and maturation of adipocytes and muscle cells, (3) scaffold or matrix on which cells can grow, (4) when to add nutrients or fat tissue/cells in order to simulate sensory and nutrient attributes of whole muscle, (5) whether to recycle water and nutrients for growth medium. Source: Adapted from Specht et al. (2018) and Bhat et al. (2019).

to proliferate and differentiate (Bonny et al., 2017). It should be noted that proliferation (increase in number of cells) is possible only at the satellite cell stage and the mononucleate myoblasts stage. Myotubes (multinucleate fused myoblasts) and myofibres (multinucleate mature muscle cells) do not proliferate and hence the importance of extensive and rapid proliferation at the stem cell and myoblast stages (Datar and Betti, 2010). Traditionally stem cells are cultivated in a medium containing nutrients and foetal, or calf, bovine serum, and the precise composition of this serum is not defined (Burton et al., 2000). Attempts have been made to synthesise serum-free growth media from mushrooms, algae and plants, but there has been limited success with these synthetic growth media (Datar and Betti, 2010; Stephens et al., 2018). In vitro cell culture is usually conducted in an aseptic environment, due to risk of contamination which can result in bacterial contamination and cell death (Sanders, 2012; Phelan and May, 2015). Cellular meat production requires a preservative, such as sodium benzoate, added to the growth media, to protect the growing cells from yeast and fungus. Sodium benzoate is a common preservative added to processed meat products (Hoang and $\mathrm{Vu}, 2016$ ). Furthermore, antibiotics are often added to the growth media of cells in long-term culture to prevent any infection from bacteria (Burton et al., 2000, Renzini et al., 2018, Stephens et al., 2018). Patents for industrial production of cell-based meat state that the process will be achieved without antibiotics (or hormones) (Van Eelen, 2007). It remains to be seen whether antibiotics, or anti-bacterials, will be routinely or occasionally required during muscle cell culture.

\section{Biomaterial/scaffold, electrostimulation and mechanical stimulation}

Similar to the need for biochemical stimulation by growth factors and hormones described earlier, biomechanical, biophysical and electrical stimulation are also necessary for proliferation, differentiation, maturation and fully functioning skeletal muscle cells.

Application of a biomechanical stimulus to satellite cells can induce the formation of muscle precursor cells (myoblasts, see Figure 2) (Langelaan et al., 2010). Biophysical stimuli are also crucial in the maturation process towards functional muscle cells with a high level of functional sarcomeres (Kosnik et al., 2003). In addition, neuronal activity is required for the development of mature muscle fibres (cells), and this can be simulated through the application of electrical stimulation (Figure 2) (Langelaan et al., 2010).

Mechanical stretch is another biophysical stimulus which can be applied and appears to be crucial in myogenesis, proliferation and differentiation. Mechanical stretch applies to various stages of the muscle cell process and facilitates; alignment of myotubes, fusion of myotubes to form muscle fibres, hypertrophy of both myotubes and muscle fibres, proliferation of myoblasts and activation of satellite cells (Vandenburgh and Karlisch, 1989, Tatsumi et al., 2001).

At the stage of differentiating from stem cells into myotubes, the cells need to be attached either to a mesh scaffold, such as a collagen meshwork, or to a carrier such as microcarrier beads, which can also be made from collagen (Bhat et al., 2015). The myotubes can then fuse into myofibres, given the appropriate cues in the growth media and environment. 
In vivo, the cells attach to the insoluble network of extracellular matrix proteins through integrin receptors located in the sarcolemma, which allows transmission of applied force to the cytoskeleton (Langelaan et al., 2010). Hence in vitro, this needs to be replicated in order to allow biomechanical and biophysical stimulation. The selection of material for the scaffold is important in cellular meat production and is indicated by decision point 3 in Figure 3 . The scaffold-based method is limited to producing a layer of cells only 100 to $200 \mu \mathrm{m}$ thick, in static culture, due the lack of blood supply and the diffusion limits for the nutrients and growth factors in the growth medium (Datar and Betti, 2010).

\section{Scaling up and industrial production}

A major challenge in cell-based meat production is to produce the nutrients, hormones and growth factors in large quantities and compatible with human food (Hocquette, 2016). All these compounds will need to be produced by the chemical industry, and the waste and pollution generated will need to be included in the environmental analysis of the effects of cellular meat production.

Identification of a self-replicating line of satellite cells is important to the process, in order to remove the reliance on animals. As myosatellite stem cells derived from a biopsy are presently the most effective source for cellular meat production, this remains a challenge for the scaling-up process.

Availability of cost-effective growth medium for cell proliferation and growth is a critical component of the scale-up process. Bovine foetal calf serum is the preferred growth media, due to its effectiveness, but is prohibitively expensive (Stephens et al., 2018), and it is derived from animals.

For differentiation, and in particular for growth, a continuous supply of nutrients and growth factors as well as a supply of oxygen and removal of waste products is required in the culture medium. This is proposed to be achieved at large scale by bioreactors having continuous agitation and flow, allowing perfusion of required gas and chemicals into and out of the cells. Certainly it is the lack of a vascular system in the current muscle cell culture systems, for both supply of nutrients and removal of waste, that presently limits the width of the muscle cell tissue to 1 to 2 cells thick, or 100 to 200 um.

Although cellular meat production is generally considered to be most feasible at an industrial scale, some companies (e.g. FM Technologies) are proposing two possible model systems where cellular meat production could occur at a small business or even individual consumer scale. FM Technologies calls this a 'distributive approach to sustainable manufacturing' (https://www.future-meat.com/). It proposes that localised production could be achieved through several models. The first model could be where farmers maintain a population of livestock for periodically deriving a source of myosatellite cells through biopsy. In this model, for example, animals could be kept in backyards, or on animal-friendly urban farms, and serve as living donors (Van Der Weele and Tramper 2014). Alternatively, the model proposed by FM Technologies has centralised stores of stem cells, which are periodically shipped to local communities. The local community would have small-scale bioreactors to feed small villages or regions, and the technological know-how would be provided from a central point. The proposed distributive approach is partly in response to the criticism that cellular meat production is likely to be controlled by multinational corporations. Also, if production occurs centrally, or even only in select countries, environmental costs associated with transport may negate any environmental benefits (Mattick et al., 2015a). These models at this stage are purely theoretical and remain to be tested or proven, and the proposed approach may struggle to be cost-effective, sustainable or efficient without involvement of large corporations and multinationals.

Recycling of growth media has the capacity to ensure industrial scale cellular meat production has a much lower water and nutrient footprint than without recycling, and this is indicated in Figure 3 by decision point 5 . The management of metabolic waste by disposal, recycling or upgrading needs to be considered for design and implementation of a hazard and critical control points (HACCP) procedure (see the 'Regulation, labelling and hazard and critical control points' section) (Stephens et al., 2018). Cell-based meat factories will need to consider constructing on-site treatment or recycling systems to limit emitted pollution, which may be required by state and federal regulations (Mattick et al., 2015a). If recycling is implemented, the emissions from excess nutrients in the waste water could be similar to, or lower than, a poultry operation (Mattick et al., 2015a). Recycling of culture medium can be enabled through the replenishment of utilised nutrients such as glucose, glutamine and other amino acids and carbohydrates and also through removal of waste products such as lactate and ammonia (Moritz et al., 2015). It is also possible that growth factors and cytokines produced by muscle cells can be reused in subsequent culture to stimulate cell growth. It is proposed that recycling would involve cells staying in the reactor and in-line recycling of media, with removal of waste products through chromatographic purification (Moritz et al., 2015). In addition, it is likely that micro-carrier beads can be recycled. The inclusion of waste water recycling in the lifecycle analysis to determine the impact on environment, emissions and water use is an important consideration.

\section{Harvesting and manufacture of cellular meat products}

Obviously the products of muscle cell culture, using collagen scaffold or micro-beads for structure, do not have the same structure as skeletal muscle tissue from animals, and can only be used for processed meat products (Datar and Betti, 2010). In addition, if the scaffold or carriers are edible, they can be included in the cellular meat mix and harvested from the bioreactor without separating cells from scaffold/carrier (Stephens et al., 2018). But this is not always desirable, as the matrix may need to be reused, the matrix may contribute an unacceptable texture, flavour or functionality to the final product or the matrix may be non-edible. In this case, removal of the cells from the matrix can be achieved through 
chemical means or through environmental manipulation of $\mathrm{pH}$, temperature and so on (van der Weele et al., 2019). Any chemicals used obviously need to pass food safety tests and achieve regulatory approval (see the 'Regulation, labelling and hazard and critical control points' section).

The flavour of meat is derived from more than $750 \mathrm{com}$ pounds. Flavour is composed of the volatiles developed during cooking that contribute to the aroma or odour and are detected in the retro-nasal cavity and the taste, which is detected on the tongue by taste receptors (Watkins et al., 2013; Frank et al., 2016). Meat derived from whole muscle has a mixture of fat cells, fatty acids in both membranes and fat cells, fibroblasts and the protein collagen, muscle and endothelial cells and compounds such as haem-iron, creatine, carnitine glutamate and other compounds which uniquely and together contribute to the overall experience of the flavour of meat. The flavour of meat develops during cooking and some fatty acids and amino acids prevalent in meat (e.g. linoleic acid and inosine monophosphate) contribute to the unique flavour fingerprint. Whether cell-based meat products will be able to replicate the $>750$ compounds associated with the flavour of whole muscle is a question that remains to be answered, as well as a challenge.

The texture of meat, mouthfeel and breakdown during oral processing contribute to the overall sensory experience. The texture, particularly hardness, of meat changes during cooking, in response to temperature, as proteins denature at different temperatures, causing shrinkage in the muscle at a macro- and micro- level and changes in the gel matrix binding proteins together (Purslow et al., 2016). Adipocytes are the main fat deposits in muscle tissue and are a rich source of aroma, taste and juiciness in the consumer's mouth (Orzechowski, 2015). Stroma, or connective tissue, comprises cells called fibroblasts, which extrude collagen fibrils to form the extracellular matrix of muscle. Both stroma and muscle cell protein integrity have important contributions not only to texture and tenderness, but also to particle breakdown and size in the mouth, and thus are pivotal in the consumer's sensory experience. Furthermore, upon prolonged heating in appropriate conditions, collagen breaks down to gelatine, which has a unique and desirable flavour, as well as contains important amino acids for human muscle function and health (e.g. glutamate) (Arihara, 2006; Toldra et al., 2012).

The tenderness and flavour of whole muscle develops during the ageing, or maturation, process postmortem. During ageing, proteases such as calpains degrade the proteins in the micro-structure, particularly the myofibrils (Koohmaraie et al., 1991). Ageing of meat is conducted in an anaerobic environment for a period of days to weeks, usually by packaging the meat in a sealed bag, after removing all air through applying a vacuum, and subsequently storing at temperatures of -1 to $1^{\circ} \mathrm{C}$. As cell-based meat products presently rely on formulation of a burger, or pattie, using only cells, the product does not need to be aged to improve tenderness. For example, beef patties are often made from cow beef, which is inherently tough, but once grinding/mincing occurs, this toughness of the whole muscle is no longer relevant. Assuming that there will be success in the future in producing whole muscle products from cells, then attention to ageing for optimal tenderness and flavour will be required.

Hence the manufacture of a product from purely muscle cells, such as cell-based meat, will have a different texture and mouthfeel to a product made from whole muscle derived from the post-mortem carcass of a living animal. This is a challenge for manufacture of cell-based meat products and requires addition of binders, such as carrageenan, collagen powder, xanthan gum or mannitol (Post, 2012) to simulate the texture derived from whole muscle.

The production of cell-based meat will be classed as a 'manufactured' meat, as it will involve the addition of ingredients for health, functionality, texture and flavour. This will likely push meat from animals into the premium end of the market, and cell-based meat products could supply the bulk, cheap end of the market if conventional meat products become more expensive and the palatability and versatility of manufactured meats improve (Bonny et al., 2017).

Aleph Farms (https://www.aleph-farms.com/), an Israeli start-up launched in 2017, announced in December 2018 that it succeeded in producing a lab-grown 'minute steak' made from bovine cells. According to its website, the tiny steaks are $3 \mathrm{~mm}$ wide - roughly the size of a very thin strip of roast beef. In the future, Aleph Farms' aim is to grow a whole steak.

The generation of a whole muscle, complete with blood supply, connective tissue, fat cells, muscle cells and associated structure, has neither been achieved in human biology and medicine nor in cellular meat production. Hence, as pointed out by Hocquette (2016), the process of producing meat products from muscle cells should be called cellular muscle production, as it contains only muscle cells. The cell-based production of a whole steak is technologically far more complex and requires technological break-throughs in providing a vascular supply through a thick layer of muscle tissue as well as determining the right growth media for co-culture of muscle, fat, connective tissue and endothelial cells.

\section{Analysis of drivers for cellular meat production}

The main drivers for cellular meat production are food security, environment, animal welfare, health and food safety. In this section, available data are presented and discussed on the likelihood that cellular meat production will satisfy the consumer concerns as well as be produced economically and in sufficient quantity.

\section{Food security and sustainable diets}

Food security is defined by the Food and Agriculture Organization (FAO) as existing when 'all people at all times have physical and economic access to sufficient, safe and nutritious food to meet their dietary needs and food preferences for an active and healthy lifestyle' (FAO, 1996, 2010; 
cited in Nelson et al. 2016). Global meat production has increased dramatically since the 1960 s to meet the increase in population and also because of the increase in affluence of consumers in some countries (Ritchie and Roser, 2017; Ranganathan, 2016). The global population is estimated to reach 9 billion by the year 2050, and according to this projection, the meat industry would need to increase production by approximately $50 \%$ to $100 \%$ to maintain per capita demand of the growing populations (Cornish et al., 2016; Bonny et al., 2017). Global meat production in 2018 was 263 million tones and is expected to reach 445 million tonnes in 2050 (Waughray, 2018). Figure 1 shows the predicted increase in the major animal-derived protein foods required by 2050 , to meet the increase in demand for animal protein. Food production in general will have to increase by at least $70 \%$ to meet both the calorie and nutritional needs of the human population (Hocquette et al., 2015; Cornish et al., 2016). The capacity of meat production, using conventional production practices, is thought to already be at its maximum, and any increase in production would come at too high a cost to the environment (Moritz et al., 2015). Cellular meat production is considered as a hopeful addition to the suite of alternative protein production systems (Van Der Weele and Tramper 2014).

Food systems have the potential to nurture human health and support environmental sustainability; however, according to some, they are currently threatening both (Willett et al., 2019). A global dietary transition, associated with 'perceived' negative effects on health and environment and characterised by an increase of animal-based diets to the detriment of plant-based diets, has occurred in the past few decades (Cliceri et al., 2018). Sustainability has become an integral component in analysis of dietary patterns and guidelines around the world (Jones et al., 2016). A sustainable diet can be defined as one which maintains long-term health while avoiding excessive degradation and consumption of natural resources (Gussow and Clancy, 1986). The most common measure of sustainability is GHG emissions (GHGEs) along with life cycle assessment (LCA, see next section). Less data are available, but recognised as of equal importance are energy, water consumption and nutrient use as well as, more recently, nutritional quality of diets (Jones et al., 2016).

It is most likely, if cellular meat production proceeds, that it will supplement the availability of meat protein from animal sources. Due to the high demand for meat protein and the potential increased consumption in many poor countries, some predictions even include a scenario where meat-animal production from agriculture is maintained alongside the development of a cellular meat industry (Stephens et al., 2018). Depending on the costs of production, cellular meat products may always be a niche product for consumers who have the income to make purchasing decisions based on their ethics. It is self-evident that for cellular meat production to be part of the solution for feeding the world, it will need to be cheap and ideally be produced locally.

\section{Environment and resource use}

Environmental sustainability is the rates of renewable resource harvest, pollution creation and non-renewable resource depletion that can be continued indefinitely (Daly, 1990). If they cannot be continued indefinitely, then they are not sustainable.

Improved GHGE efficiency of production has been proposed as one of the biggest potential advantages of cultured meat over conventional livestock production systems (Lynch and Pierrehumbert, 2019). In fact, meat production, particularly beef production, is considered to be the greatest single contributor to GHGE of any industry (Lynch and Pierrehumbert, 2019). Thus the supporters of cellular meat production propose it is more sustainable as it will produce much lower GHGEs (Tuomisto and Teixeira de Mattos, 2011).

There are still substantial uncertainties in most components of the GHG balance of livestock production systems, method of ranking and LCA methodologies, and these depend on assumptions, approach and criteria selected, for example, GHGEs per unit land area, per kilogram livestock or per unit product. The reader is directed to reviews on the methodological challenges in both LCA (Cederberg et al., 2013; Sala et al., 2017) and in calculation of GHGEs (Crosson et al., 2011) for further detail. In order to compare GHGE across species, the work of one author has been selected to ensure a consistency of assumptions and methods. The GHGEs per kilogram $\mathrm{LW}\left(\mathrm{kg} \mathrm{CO}_{2}\right.$-e/kg LW, excluding land use and direct land use change emissions) from meat production systems in Australia vary from the lowest for pork (2.1 to 4.5) (Wiedemann et al., 2018), grass-finished lamb is intermediate (6.1 to 7.3) (Wiedemann et al., 2016b) and grass finished beef is the highest (10.6 to 12.4) (Wiedemann et al., 2016a). The calculation for grass-fed beef and lamb does not take into account carbon sequestration and storage by permanent pastures, and if this is included, the carbon impact will reduce by $30 \%$ to $50 \%$ (Soussana et al., 2010). For pork, the GHGEs per kilogram wholesale meat were also estimated and were $6.36 \mathrm{~kg} \mathrm{CO}_{2}$-e/kg of wholesale pork (Wiedemann et al., 2018) and 2.5 to 3.1 for boneless chicken (Wiedemann et al., 2017b).

The resources used and GHGEs from production of $1 \mathrm{~kg}$ of ready-to-eat product have been modelled for comparison across dairy-protein, chicken meat, cell-based meat and other forms of protein, including traditional (soya, wheat) and novel forms (insect-protein, myco-protein) (Smetana et al., 2015). Cell-based meat production was predicted to require 2 to 10 times the amount of energy, vastly more tap water and have moderate-to-low requirements for transport (Table 1). The GHGEs from cell-based meat production were predicted to be much higher than for the other protein types by Smetana et al. (2015), but others predicted much lower GHGEs from cell-based meat, which were comparable to the levels for other protein production systems. Cell-based meat production also had much higher predicted nonrenewable energy usage than the other protein production systems in the modelling of Smetana et al. (2015), and in this 
Warner

Table 1 (a) Resources used per functional unit (FU, $1 \mathrm{~kg}$ of ready-to-eat product) from cradle to grave in the production of different protein-based meals (b) comparison of the greenhouse gas emissions (GHGEs) and non-renewable energy use per $1 \mathrm{~kg}$ of ready-to-eat product (FU)

\begin{tabular}{|c|c|c|c|c|c|c|c|c|}
\hline & Chicken & Dairy & $\begin{array}{c}\text { Cellular- } \\
\text { based meat }\end{array}$ & $\begin{array}{l}\text { Insect- } \\
\text { based }\end{array}$ & $\begin{array}{l}\text { Gluten- } \\
\text { based }\end{array}$ & Soya-based & $\begin{array}{l}\text { Myco-protein- } \\
\text { based }\end{array}$ & References \\
\hline \multicolumn{9}{|l|}{ (a) Resources used } \\
\hline Electricity (MJ) & 49.78 & 12.27 & 103.5 & 10.762 & 8.94 & 10.002 & 21.32 & $\begin{array}{l}\text { (Smetana } \\
\text { et al., 2015) }\end{array}$ \\
\hline Tap water $(\mathrm{kg})$ & 16.3 & 4.2 & 420 & 1.34 & 0.954 & 0.73 & 40 & $\begin{array}{l}\text { (Smetana } \\
\text { et al., 2015) }\end{array}$ \\
\hline Transport (km) & 850 & 360 & 110 & 128.5 & 141.1 & 2791 & 215.45 & $\begin{array}{l}\text { (Smetana } \\
\text { et al., 2015) }\end{array}$ \\
\hline \multicolumn{9}{|c|}{ (b) GHGEs and non-renewable energy } \\
\hline $\begin{array}{l}\mathrm{GHG}, \mathrm{kg} \mathrm{CO} \\
\text { eq./kg }(\mathrm{FU})^{12}\end{array}$ & $5.2-5.82$ & $4.38-4.95$ & 23.9-24.64 & $2.83-3.02$ & $3.59-4.03$ & $2.65-2.78$ & $5.55-6.15$ & $\begin{array}{l}\text { (Smetana } \\
\text { et al., 2015) }\end{array}$ \\
\hline $\begin{array}{l}\text { Range in values for } \\
\text { other references } \\
\text { (no. of references) }\end{array}$ & $\begin{array}{r}1.3-5.5 \\
(n=7)\end{array}$ & $\begin{array}{r}3.8-6.2 \\
(n=1)\end{array}$ & $\begin{array}{r}1.8-10 \\
(n=2)\end{array}$ & $\begin{array}{r}2.7-20 \\
(n=2)\end{array}$ & $\begin{array}{l}1.55 \\
(n=2)\end{array}$ & $\begin{array}{c}0.34-3.72 \\
(n=2)\end{array}$ & $\begin{array}{r}2.4-2.6 \\
(n=1)\end{array}$ & $\begin{array}{l}\text { See } 17 \text { references } \\
\text { in Smetana } \\
\text { et al. (2015) }\end{array}$ \\
\hline $\begin{array}{l}\text { Non-renewable energy } \\
\text { use, } \mathrm{MJ} / \mathrm{kg}\left(\mathrm{FU}^{1}\right)\end{array}$ & $51.64-63.4$ & $48.79-59.1$ & 290.7-373 & $32.0-40.4$ & $39.7-49.2$ & $27.78-36.9$ & $60.07-76.8$ & $\begin{array}{l}\text { (Smetana } \\
\text { et al., 2015) }\end{array}$ \\
\hline $\begin{array}{l}\text { Range in values for } \\
\text { other references }\end{array}$ & $1.3-54$ & 55.5 & $25.2-31700$ & $34-170$ & $1.4-2500$ & $1.5-3000$ & 38 & $\begin{array}{l}\text { See } 17 \text { references } \\
\text { in Smetana } \\
\text { et al. (2015) }\end{array}$ \\
\hline
\end{tabular}

Source: Derived from Smetana et al. (2015).

${ }^{1} \mathrm{FU}=$ functional unit and is $1 \mathrm{~kg}$ chicken, $6 \mathrm{~kg}$ skimmed milk.

${ }^{2}$ For comparison to pork in this table, global GHG emissions for pork are relatively similar to chicken meat ( $6.1 \mathrm{v} .5 .4 \mathrm{~kg} \mathrm{CO}$-eq/kg CW respectively; MacLeod et al., 2013 ) and are much lower than beef and sheep meat (see text and Wiedemann references).
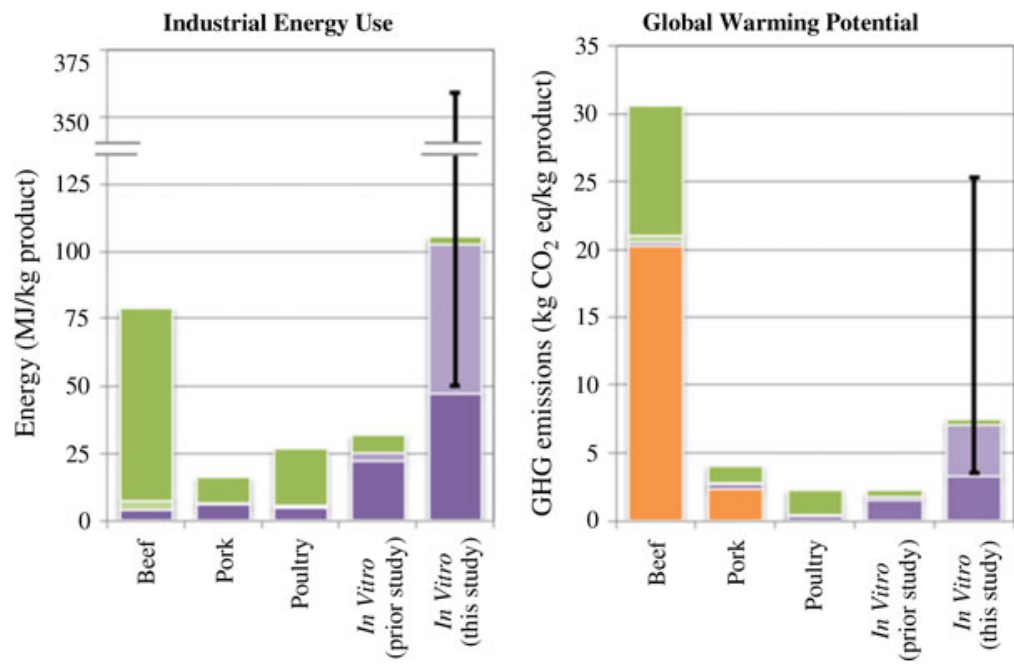

Figure 4 (Colour online) A comparison between beef, pork, poultry and cellular (in vitro) meat production for the energy usage and GHGE (greenhouse gas emission) attributed to agricultural production including feedstock processing and transport (green and light purple), on-farm energy use for livestock and biomass cultivation, bioreactor cleaning and facility (dark purple) and animal/carnery waste products for livestock/cellular meat (orange). Source: From Mattick et al. (2015c).

case, the comparisons across protein types by other authors were extremely variable.

Mattick et al. (2015a) compared beef, pork, poultry and cellular meat production (see Figure 4), and their modelling showed that the predicted global warming potential of cellular meat production was approximately equivalent to (previous study), or higher than (current study), that of pork and poultry production, but much lower than that attributed to beef production. The predicted energy usage of cellular meat production was four times higher than that of pork and poultry and beef production, which is consistent with the more recent study of Lynch and Pierrehumbert (2019).

Lynch and Pierrehumbert (2019) recently modelled the potential climate change impacts of four cell-based meat production systems and three beef cattle production systems, over 1000 years (Figure 5). In both scenarios of perpetual 
(A)

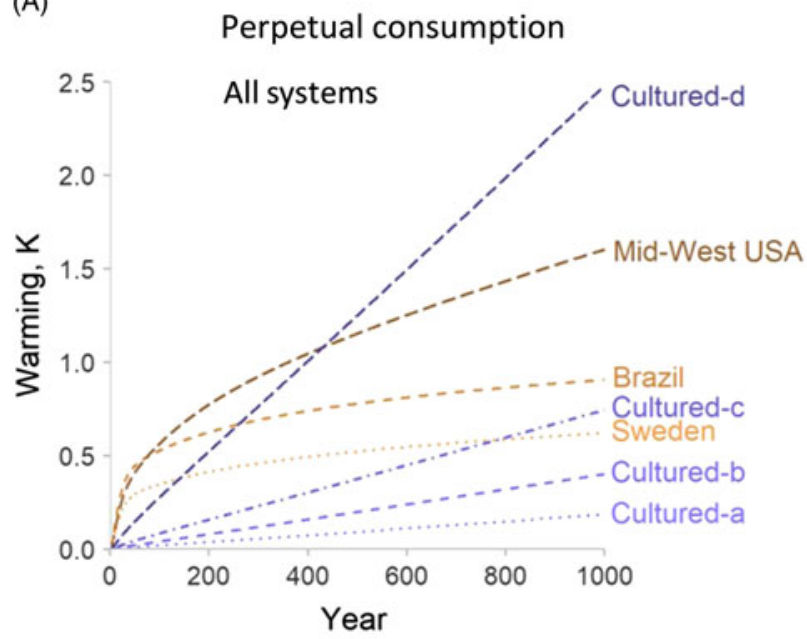

(B)

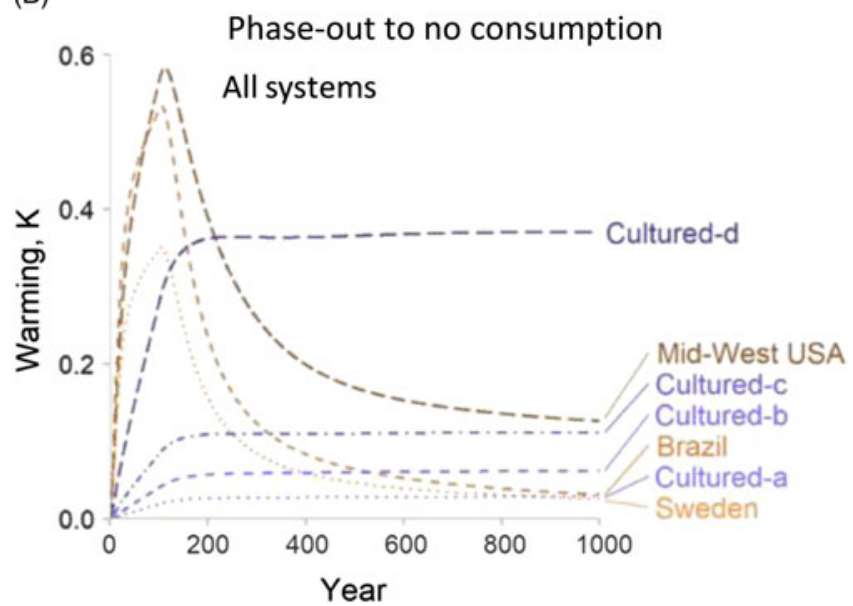

Figure 5 (Colour online) Predicted environmental warming impacts for the production of beef cattle, under three different cattle production systems (Brazil, Sweden, mid-West USA) or cellular meat production (cultured; alow emissions system, b- and c- moderate emissions systems, $d$ - high emissions system) under these production systems $(a, b, c, d)$ for 1000 years. (A) - assumes perpetual consumption at very high rates ( $250 \mathrm{Mt}$ per year), (B) - assumes initial consumption at very high rates followed by a decline to zero consumption. Source: Derived from Lynch \& Pierrehumbert (2019).

consumption of animal protein, and phase-out to no consumption, the warming potential of one cellular meat scenario (cultured-d, high emissions system in Figure 5a and b) would exceed the warming potential of beef production in Brazil, Sweden or USA. The predicted warming potential of cellular meat production ' $b$ ' and ' $c$ ' (medium emissions system) was similar to that for mid-West USA cattle production. They concluded that cultured meat is not 'prima facie' climatically superior to cattle. The conclusion of Lynch and Pierrehumbert (2019) is that 'replacing cattle systems with cultured meat production before energy generation is sufficiently decarbonised could risk a long-term, negative climate impact'.

In summary, the existing data are consistent in showing that cell-based meat production has similar levels of GHGEs to pork and poultry production but much lower than beef production. The studies also consistently demonstrated

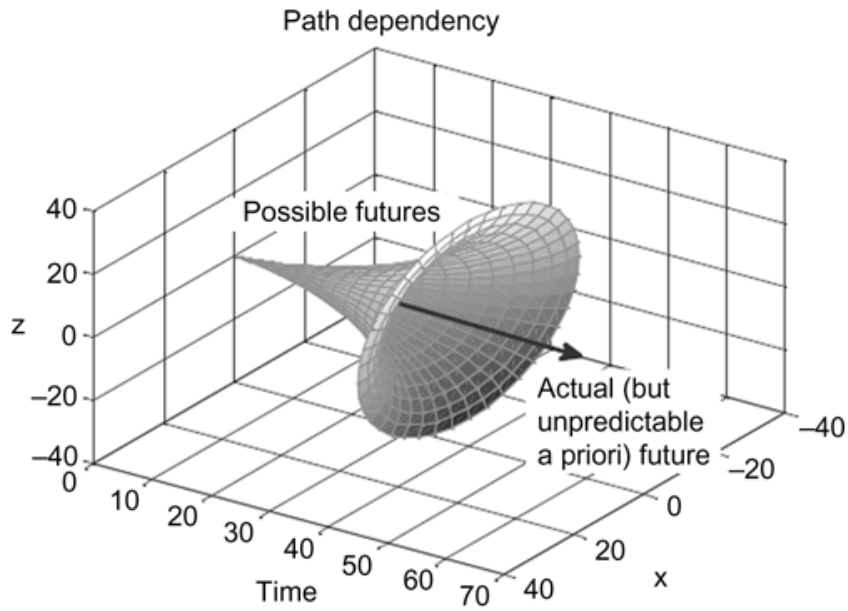

Figure 6 (Colour online) Path dependency and unpredictability inherent in the evolution of complex systems over time. Source: From Mattick et al. (2015a).

that cell-based meat production will have much higher nonrenewable energy usage, and likely higher water usage. Hence the environmental impact of cell-based meat may be comparable, or even worse, than traditional forms of animal-based production systems, especially if compared to pork and poultry. It should be noted that there was considerable variability in the methods used, and the assumptions made, in each study. As cell-based meat production is not yet occurring, a number of assumptions have been made, and will need to be made, regarding an industry scale system. Mattick et al. (2015a, 2015b, and 2015c) who have studied the environmental consequences of cell-based meat production, as well as cellular agriculture, state that 'because the cellular agriculture technology largely replaces biological systems with chemical and mechanical ones, it has the potential to increase industrial energy consumption and, consequently, greenhouse gas emissions'. Mattick et al. (2015a) have also explained that in the absence of a commercial-scale process on which to base a lifecycle inventory (i.e., the detailed methodology), any analysis of the environmental implications cannot be interpreted as conclusive or definitive. Taking into account Mattick's comments, the need for further research and development on the industrial process (Figure 2) and the unpredictability of the future of a complex system (Figure 6) such as cell-based meat production, the effects on the environment are, in fact, unpredictable. But as the environment is a major driver for the development of cellbased meat production, the modelling should continue and hopefully improve as the process is better defined and commercial production is initiated.

\section{Public and consumer health}

Our pre-human ancestors ate meat, and the consumption of meat is thought to support the historical early development of a larger and more elaborate brain which required the diversion of energy from the gastrointestinal tract, resulting in a reduction in the size of the tract relative to other species (Mann, 2018; Willett et al., 2019). Humans cannot digest 
plants and grass, and eating meat from herbivores is an efficient way for human beings to valorise grass (Post, 2012).

The effect of cell-based meat production is a topic where there is, in some instances, a big gap between consumer/ public perception and reality. Some of the reported consequences of red meat consumption include nutrition-related diseases, foodborne illnesses and antibiotic-resistant pathogens strains, due to overuse of antibiotics. In addition, some of the perceived problems with consumption of animalderived meat include the use of growth hormones and 'chemicals' in animal production. Hopkins (2015) shows evidence of the overemphasis and overrepresentation of the views of vegetarians in the media, particularly in regard to the reception of cell-based meat among vegetarians.

Nutrient attributes of animal-derived meat. Meat is well known to be a good source of high-quality protein, including essential amino acids, Vitamin $B_{12}$, iron, zinc and selenium. For example, from $100 \mathrm{~g}$ of pork, the consumer derives $\sim 37 \%$ of their daily protein requirements, $67 \%$ of their daily Vitamin $B_{12}$ requirements and $15 \%$ to $16 \%$ of their selenium and zinc requirements (McAuliffe et al., 2018). Thus in order to compare foods, it is important to compare them not only on a nutrient basis but also on a nutrient bioavailability and gut health basis. The most well-known example is the much lower bioavailablity of non-haem iron from plants, as a source of iron, relative to haem iron from meat sources. Animal-source foods are also the only natural source of Vitamin $B_{12}$, so deficiency is prevalent when intake of these foods is low due to their high cost, lack of availability or cultural or religious beliefs (WHO, 2008). Meat is known to be the biggest source of protein for human consumption.

Nutrients predicted to be in cell-based meat. In order for cell-based meat products to supplement meat from animals, they will need to either replicate or increase bio-availability and levels of the nutrients referred to earlier. Skeletal muscle cells can make many bio-available proteins, fatty acids, growth factors and cytokines. But Vitamin $B_{12}$ is not produced by muscle cells in culture, but is taken up from the culture media in vitro or from the blood in vivo (Post and Hocquette, 2017). Cellular meat does not have high levels of iron, unless the culture is grown under a low oxygen environment (Post and Hocquette, 2017). Furthermore, many of the healthy $n-3$ fatty acids and poly unsaturated fatty acids are generated from the animals diet (McAuliffe et al., 2018). As the levels of the healthy $n-3$ fatty acids in the membranes of muscle cells in culture may be low, these fatty acids could be added to cell-based meat products as a 'health bonus' (Post, 2012). Vitamin $B_{12}$ needs to be added to the culture medium in order for the cell-based meat to contain this vitamin. In general, the nutritional composition of the cellular meat will be dependent on the nutrients added to the growth medium during production, unless these can be added as fortifications to the product (see decision point 4 in Figure 3).

Diet-related diseases. Consumption of meat, particularly red meat, has been related to obesity, atherosclerosis, cardiovascular disease and colon cancer, although some of the constituents related to these diseases may be produced during cooking (e.g. heterocyclic amino acids) (Post, 2012; Orzechowski, 2015), hence it is possible that cell-based meat culture could be tailored to remove specific compounds. In addition, there is evidence that the incidence of these dietrelated diseases is due to overconsumption of food, and of meat. Hence the evident solution is for affluent Western countries to reduce intake.

Pathogens and animal transmission of diseases. Foodborne pathogens, such as Salmonella, Campylobacter, Listeria and Escherichia coli, are responsible for many cases of illness, and sometimes death, around the world. Over the period 2009 to 2016 in the US, the single source foods that sickened people the most were fish (17\%) and dairy $(11 \%)$ followed by chicken $(9 \%)$ and beef, pork, vegetables and molluscs being lower (6\% to $8 \%$ ) (https://www.cdc.gov). Epidemiological studies demonstrate that these pathogens and emerging diseases such as avian and swine influenza increase in incidence under intensive production and housing. Also, cell-based meat production will reduce the human-animal interactions and thus is expected to reduce incidences of epidemic zoonoses and other emerging diseases (Datar and Betti, 2010). Interestingly, strains of pigs and poultry which are resistant to Salmonella are being developed (Bonny et al., 2015), and there is potential for technological advances in this area. The high degree of environmental control required for cell-based meat production will likely reduce the risk of foodborne pathogens and may allow improvements in health and safety (Bonny et al., 2015).

Anti-microbials and chemicals. The use of sterile environments and antimicrobials during cell-based meat production will likely be used to eliminate pathogens such as Salmonella and $E$. Coli from the production process. Historically, the extensive and long-term use of antimicrobials is known to generate public and consumer health and safety issues. In addition, generating the required sterile environment during production is very expensive and is very difficult at an industrial scale (Bonny et al., 2017). This is exemplified by the consideration that sterile environments for cell culture can be difficult to maintain long term at lab scale (see 'Growth media for proliferation, merging and maturation' section), let alone at an industrial scale, and hence the likelihood that strong chemicals and anti-microbials will be required in the production process. Conversely, there will be reduced exposure to dangerous chemicals in animal production such as pesticides and fungicides (Post, 2012) which can be injurious not only for humans if ingested but also for wildlife.

Growth hormones. As discussed in the 'Growth media for proliferation, merging and maturation' section, large-scale production of cell-based meat will likely require the addition of natural, or artificially manufactured, growth hormone (Post, 2012). This is not problematic for public or consumer health, as the growth hormone would not remain in the harvested tissue. But one of the big concerns consumers have about animals-based meat production is the use of growth hormones (and steroids) (Gatti, 2019). Hormonal growth promotants (HGPs) are naturally occurring hormones such as oestrogen, or synthetic alternatives, and are used on about 
$40 \%$ of Australian cattle to accelerate weight gain (FoodStandards-Code-Australia, 2011). According to research by the European Federation of Animal Health, a single consumer would need to eat more than $77 \mathrm{~kg}$ of beef from an HGPtreated beast in one sitting to get the same level of oestrogen hormone found in one egg (Food-Standards-Code-Australia, 2011). Hence on this aspect, the consumer 'perception' of cell-based meat may be far removed from reality.

Cell-based meat can be engineered to be healthier and more functional by either manipulating the culture media to change levels of nutrients, vitamins, fatty acids or fat content (Bhat et al., 2015). Levels of these nutrients can also be controlled through addition post-harvest, but of course this can occur in any manufactured meat product and is not unique to cell-based meat.

\section{Animal welfare}

Ethical issues are increasingly important in our food choices, and the consequence has been the development of societal concerns. According to Cornish et al. (2016) 'the production of food from animals poses many ethical challenges'. These societal concerns are varied and encompass the right to kill animals and to prevent any suffering of animals (Hocquette, 2016). Implicit in the prevention of suffering, often espoused by vegans and vegetarians, is the erroneous perception that all animals raised on farms undergo 'suffering'. In a similar manner, some consumers use anthropomorphic considerations and assume animals in pens, or in intensive livestock system or in feedlots, undergo suffering. It is mostly consumers in industrialised, wealthy, Western cultures who hold these views, whereas consumers in less industrialised, lower wealth economies generally do not hold these views (Cornish et al., 2016). If cell-based meat production requires a regular, or irregular, biopsy sample from an animal, it is not clear whether this will allay the ethical concerns some consumers hold around animal production.

A major limitation in cell-based meat production is the need for a supply of bovine serum for the culture medium. About $50 \mathrm{I}$ of bovine serum is required to make one burger (Mark Post cited on https://www.wired.com.uk), and this volume of serum requires blood from 91 to 333 foetuses (3-month-old foetus has $150 \mathrm{ml}$ of blood, near full-term foetus has $550 \mathrm{ml}$ of blood) (Jochems et al., 2002). Hence until animal-free serum is available for muscle cell culture at industrial scale, the production of cell-based meat products will not meet consumers' demands for animal welfare. Consideration of animal welfare in traditional animal production, and in cell-based meat production, is likely the most polarising and contentious of the consumer concerns.

\section{Food safety}

Safety is a very important issue for animal products (Hocquette, 2016). Many consumers hold misperceptions that antibiotics, growth hormones and steroids/anabolics are used in all forms of animal production for meat. Certainly, and for good reason, the proliferative use of antibiotics for prophylactic reasons, and also as growth promotants (mainly in the poultry industry), needs to undergo dramatic reduction. Hence some argue that cellbased meat will be safer to eat. In addition, promoters of cellular meat argue that it will be free of microorganisms and parasites, as it will be produced without animals. However according to some, the high rate of proliferation required of stem cells will likely produce genetic instability which may result in sporadic cancerous cells (Hocquette, 2016), which will require monitoring in HACCP plans (see later). At this stage it is unclear whether the growth hormones, nutrients and other chemicals (antibiotics, preservatives such as sodium benzoate) added to the growth media are safe in the context of human food, and this will need to be investigated and documented.

A key concern of regulators (see the 'Regulation, labelling and hazard and critical control points' section) will be food safety which requires implementation of auditable procedures in each step of the production chain as part of a HACCP plan for each individual company (see the 'Regulation, labelling and hazard and critical control points' section).

\section{Consumer acceptance}

Perhaps the most significant challenge for cell-based meat to overcome is that of consumer acceptance (Bryant and Barnett, 2019). There is a diversity of opinions in the media regarding consumer acceptance and consumer concerns. Unfortunately, much of this is driven by the media, and the media tends to report itself, as well as over-representing the vegan and vegetarian point of view (Hopkins, 2015). The diversity of opinion is well represented by comments on a news release titled 'Lab grown meat could be in restaurants by 2021, cutting down land and water required to produce red meat by more than $90 \%$ ' (Gatti, 2019). The comments included quite a few stating that 'lab meat will have less chemicals, less pesticides, no antibiotics and no hormones' as well as 'meat grown in a lab is disgusting and we already have too much Frankenfood in the USA' and 'does not sound natural or appetising' with the majority of other comments being around 'how great to cease producing and slaughtering animals'. Although some people also commented 'how sad it will be to no longer see animals and sheep as part of the rural landscape', some of these comments are very ill-informed, as it is likely that cell-based meat will be produced using more chemicals than animal-based meat production. Certainly these comments reflect the urban consumers' 'perceptions' of animal-based meat production. Surveys conducted show that between $16 \%$ and $66 \%$ of consumers would be prepared to eat cell-based meat products although the concerns around cell-based meat include the perceived unnaturalness, perceived risks to human health and uncertainty regarding price and taste (Bryant and Barnett, 2019). Consumer acceptance can only be theoretical as no product is presently available to display to consumers or to allow taste tests, and the perceived consumer acceptance is highly dependent on how the product is named (and framed). Using the name 'clean' meat or 'animal-free' 
meat invokes positive attitudes from consumers compared to using the names 'cultured' meat or 'lab-grown' meat (Bryant and Barnett, 2019).

Many consumers do not think that cellular meat production will be the solution to reducing meat production; rather they prefer to reduce their meat consumption (Hocquette et al., 2015). In fact, in a survey of 817 educated people, participants were not convinced that cellular meat production will be tasty, safe or healthy (Hocquette et al., 2015). Concerns about cellular meat production as an unnatural and risky product also appear to be a significant barrier to public acceptance of the product (Bhat et al., 2017). Generally speaking, people might be ready to taste cell-based meat products but may not want to regularly consume cell-based meat either in restaurants or at home (Verbeke et al., 2015).

\section{Regulation, labelling and hazard and critical control points}

Before it can reach the shelves, cell-grown meat will be required to go through regulatory hurdles and paperwork. There are presently 44 companies listed on the Australian clean meats website (https://www.cleanmeats.com.au), and of these, 19 are in the US. For the cellular meat industry in the US and other countries to succeed, companies need assurance that their product will be responsibly regulated, in the case of the US, by the United States Department of Agriculture (USDA) and the Food and Drug Administration (FDA). Although literature has existed on the considerations for regulation of cultured meat since 2013 to 2014 in both the US and the European Union (EU), this literature identified the regulations in place at the time were inadequate to deal with cell-based meat production without significant development (Stephens et al., 2018). The considerations in the US were that if the production is defined as explant (expanding existing muscle tissue), it would require FDA New Animals and Drugs application whereas if scaffold-based, this should follow FDA food additive regulation. Whereas in EU, cellbased meat production would be subject to novel food regulation via the European Food Safety Authority (EFSA) risk assessment. The exception here is that the EFSA novel food regulation excludes genetically modified food, which may not be the case for cell-based meat (Stephens et al., 2018).

In November 2018, the USDA and FDA announced an agreement for a joint regulatory framework for the production of cell-cultured food products derived from livestock and poultry. The agreement outlines the point of transfer as follows. 'FDA oversees cell collection, cell banks, and cell growth and differentiation. A transition from FDA to USDA oversight will occur during the cell harvest stage. The United States Department of Agriculture will then oversee the production and labelling of food products derived from the cells of livestock and poultry' (Piper, 2019; Rollins and Rumley, 2019). This agreement was formalised on 7 March 2019 in a memorandum signed by principals from
USDA and FDA laying out the delegation of responsibility (Piper, 2019; Rollins and Rumley, 2019); however the details concerning inspection and the labelling process are still to be worked out by the respective agencies.

In some states in the US (e.g. Missouri), legislation has been introduced and sometimes passed, prohibiting cellbased meat companies from using the label 'meat'. The United States Department of Agriculture's labelling authority overrides that of the states; hence the USDA's future ruling on what cell-based meat can be called will, in theory, be final. Cultured meat has already faced resistance from the US meat industry and will probably face a labelling battle once it comes on the market. Hence law suits and fights will likely proceed in court, whatever labelling the product has finally approved by the USDA (Piper, 2019).

In Europe, a Brussels agriculture committee has approved a ban on producers of vegetarian food using nomenclature usually deployed to describe meat (Boffey, 2019). Instead proposed that terms such as 'veggie discs' rather than 'veggie hamburger' be used. The proposed terms will now be voted on by the full parliament after May's European elections, before being put to member states and the European Commission. After the vote in the European Parliament on revisions to a food-labelling regulation, it is likely that any introduction of cellular meat products will face similar restrictions in labelling, particularly as Europe tends to be far stronger in banning any foods associated with increased chemical use during production, which is likely to be the case with cell-based meat. The possibility of cell-based meat being better for animal welfare may sway European regulators to be more lenient, as Europe in general is strongly pro-animal welfare.

In order to develop regulatory guidelines, the procedures for production must be clearly outlined. At this early stage, procedures are not developed; thus regulations will need to follow the development of documented procedures, and there are likely to be several or many pathways for production. Regulations presently being developed in USA and EU will be watched closely for providing guiding principles to regulators in other countries, where a cell-based meat production industry is developing.

Regulatory guidelines, HACCP plans and auditing will need to consider a number of steps and aspects, including governance at local, state and federal levels. The initial collection of samples will be governed by animal welfare acts. A HACCP plan is designed as a preventative food safety system in which every step in the manufacture, storage and distribution of a food product is scientifically analysed for microbiological, physical and chemical hazards. Thus for the production and processing of cell-based meat, a HACCP plan will be required to specify auditing for identification of all possible pathogens, possible physical contamination and the safety of chemicals added, including methods to prevent contamination at each HACCP step that are usually subject to either state or federal government agencies, depending on whether the product will be consumed locally or exported. Auditing procedures for cell-based meat 


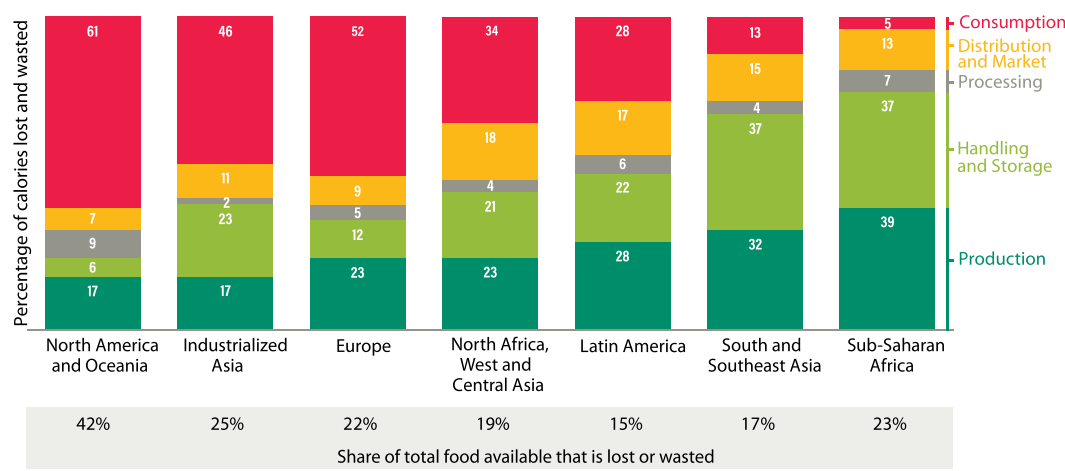

Figure 7 (Colour online) Food lost or wasted by region and stage in the value chain in 2009 (percentage of kilo calories lost and wasted). Source: From Lipinksi et al. (2013).

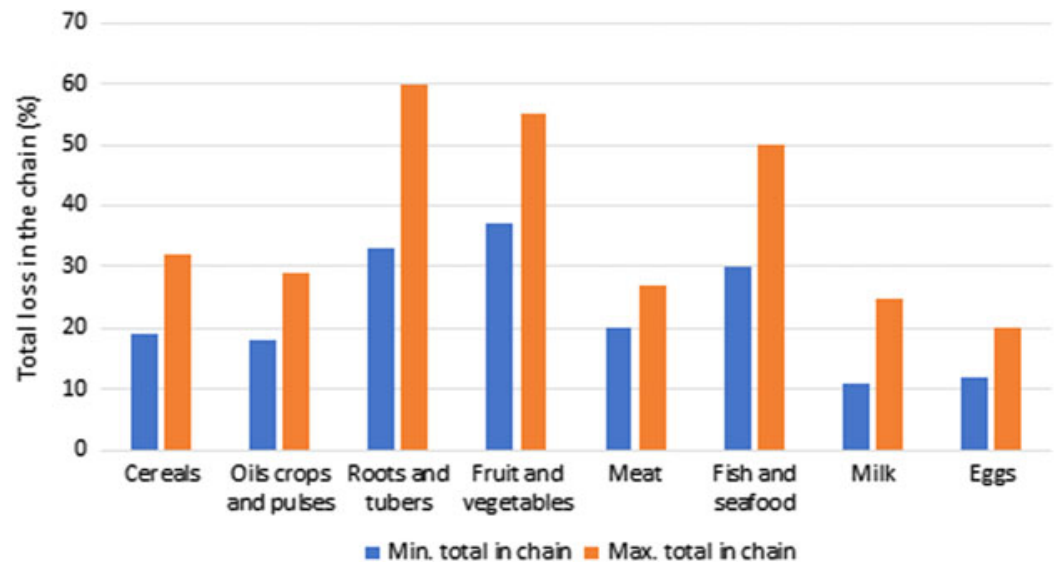

Figure 8 (Colour online) Total losses (\%) in the chain for different categories of food. Source: Derived from data in FAO (2011).

production will also likely need to include monitoring and quality assurance function at each stage, testing of genetic stability and management of metabolic waste by disposal or recycling (Stephens et al., 2018).

\section{Other possibilities to address consumer concerns and food security}

There are other possibilities to address consumer concerns and food security. Some of these are already in progress and have variable implementation in countries around the world; others have been researched and are yet to be implemented, and some possibilities require extensive research. These are discussed here.

\section{Meat substitutes}

There has been a rapid increase in plant-based protein products on the supermarket shelves, many of which are presented in a simulated meat form, such as veggie burger and veggie sausages. The mainstream meat substitutes include soy-based products, wheat-based products, pea protein and mycoproteins with a high and increasing value in the world markets (Hocquette, 2015). Protein for meat substitutes can also be derived from algae and insects (see Table 1). Consumers are increasingly aware of the potential health benefits of the meat substitutes; hence the demand is centred around good health and wellness. The global meat substitute market size was estimated at US\$3.71 billion in 2016 with projections of expansion by $7.5 \%$ every year to 2022 (Grand-ViewResearch, 2018). Growing preference towards a vegan diet owing to several health benefits and environmental concerns is the major factor driving the market. There are many companies with products in the substitute meat market, and three important companies with high publicity include Impossible Foods (US) that produces a burger that 'bleeds', Beyond Meat whose products are made from pea protein and Quorn Foods Ltd (UK) that have been around for a while. Many consider meat substitutes manufactured from plant proteins and mycoproteins will have a greater potential than cellbased meat in the near future (Bonny et al., 2015).

Reduce food waste or increase utilisation of waste streams from manufacturing

In 2013, it was estimated that approximately one-third of all food produced was wasted (Hocquette, 2016). This varies with region as North America and Oceania show the highest food waste of $42 \%$ compared to the lowest of $15 \%$ for Latin America (Lipinski et al., 2013) (Figure 7). Hence reductions in food waste will have a direct benefit for increasing food security, while addressing environmental concerns by increasing efficiency. This waste occurs on the farm, during transport, manufacturing, storage, at retail and also in the consumer's home. For North America and Oceania, most of the waste 
(61\%) occurs during consumption, whereas for sub-Saharan Africa, most of the waste $(39 \%)$ occurs during production (Lipinski et al., 2013) (Figure 7). The waste also varies significantly with commodity; the total loss in the chain for meat is in the range of $20 \%$ to $27 \%$ compared to roots and tubers where the total loss is 33\% to 60\% (Figure 8) (FAO, 2011).

Extraction of protein and macronutrients from all parts of the animal and also from waste streams of animal processing and conversion from non-edible to edible is also important. The yield of the carcass (fat, muscle and bone) expressed as a $\%$ of the live weight of an animal is about $50 \%$ to $55 \%$ for sheep and cattle and $70 \%$ to $75 \%$ for pigs and poultry. The proportion of carcass meat from the animal is only $~ 33 \%$ for cattle and sheep with $\sim 13 \%, \sim 10.5 \%$ and $3.5 \%$ of the animal comprising organs, skin/hides and blood, respectively (https://meattechnologyblog.blogspot.com/2014/01/carcassyield.html). Trimmed fat and muscle are retained and utilised for manufacturing, but for example, often blood and also bone end up as blood and bone meal for animal feed. There are many opportunities to extract more edible nutrients from the animal, including from blood, organs, hides and hoofs/trotters (Toldra et al., 2012 and 2016). Westernised countries often 'waste' or underutilise parts of the animal that other cultures prize for the recognised nutritional value. Some religions focus on respect for the life of an animal being slaughtered, including offering a prayer of thanks for every animal slaughtered (Farouk, 2013; Farouk et al., 2016). A component of respecting the life of animals, and their use for human food, should include efficient use of the whole animal, rather than focusing on just the skeletal muscle for human food.

\section{Dietary changes, re-distribution of nutrients}

In 2013, the US and Australia were the highest annual consumers of meat (excluding fish and seafood) in the world, being in the range of 115 to $116 \mathrm{~kg} /$ person per year compared to the majority of the African continent which has an average annual consumption of 5 to $40 \mathrm{~kg} /$ person per year (Ritchie and Roser, 2017). It is well recognised that the high levels of obesity, CVD and other diseases could be reduced in affluent societies, including Australia and US by reducing food consumption, including meat. Malnutrition is an underlying cause of death of 2.6 million children each year, while anaemia, from a lack of iron in the diet, affects $35 \%$ of the world's population (https://www.gainhealth.org/about/). Thus it is clear that while affluent societies need to decrease their food, and meat consumption, the poor countries suffering drastically need to increase their food, and also meat consumption.

Many consumers consider animal products to be the most desirable way to access nutrient-rich and tasty protein. Meat is commonly perceived as the core of protein delivery as it has more protein, micronutrients and amino acids per kilogram of all the dietary protein sources (Waughray, 2018). In addition, consuming meat is considered a sign of affluence for the world's emerging middle classes. Alternatives to meat exist, and young people seem to be shifting towards 'non-meat'- based food. It will be interesting to observe how far this shift to plant-based meals occurs as there is a predicted increase in the consumption of all meats (beef, pork, poultry, sheepmeat) across all of the continents and all of the 31 diverse countries included in the FAO (2018).

Considering a strict vegan diet (no milk, eggs, meat, dairy) is associated with a higher risk of nutrient deficiencies, especially in the vulnerable young and elderly (Hocquette, 2016), and this does not seem to be a solution to the concerns around animal production across all consumers in all countries.

\section{Improvements in animal welfare}

Alternative ways to consider the animal welfare aspects of animal production are to evaluate the critical points where animal welfare may be compromised and introduce technological innovation and industry transformation in how meat is produced.

Research has been conducted on the stressors encountered between farm and slaughter (Grandin, 1997 and 1998; Ferguson and Warner, 2008; Warner et al., 2010) and the effects on meat quality (Voisinet et al., 1997; Warner et al., 2007; Edwards et al., 2010), and some of the results have been implemented, resulting in improvements in animal welfare. Recently, infra-red video cameras have been used to measure physiological stress responses on the farm and at the slaughter plant (Jorquera-Chavez et al., 2019). These technologies offer promise for continuous monitoring of stress as well as disease throughout the life of the animal, potentially enabling continued improvements in animal welfare. The Danes have developed low-stress handling systems for handling of pigs pre-slaughter which have demonstrated improvements in welfare as well as in meat quality (Aaslyng and Barton-Gade, 2001), hence less wastage.

The European Union-funded Welfare Quality ${ }^{\circledR}$ project was a very large project with significant outcomes for defining and standardising welfare and developing animal-based measures across the EU and also in other countries (Blokhuis et al., 2010). Interestingly, retailers and the food industry, in some countries such as those in Europe, and also Australia, have been very successful in identifying a consumer demographic who responds to issues of animal welfare and food quality (Buller et al., 2018). This demand for higher welfare supply chains has been met by retailers as there is now a commodity value on welfare, in some countries. As a result of both consumer demand and retail recognition of the commodity value of animal welfare, livestock production practices in many countries have recently shown significant improvements through incorporating new concepts to improve animal welfare and reduce animals suffering (Hocquette and Chatellier, 2011).

Mobile slaughter units are being developed around the world, where the slaughtering occurs either on the farm or in a small village or town (Carlsson et al., 2007; Eriksen et al., 2013), and these are predicted to reduce the stressors as well as environmental costs attributed due to transport of animals. These approaches listed earlier will never satisfy the 
consumers committed to cessation of all forms of animal production; although this segment is vocal and media-grabbing, they are not the majority of the population.

\section{Changes in livestock production}

In the future, the quality of animal products will be defined by the sustainability of the production system (Scollan et al., 2010). There has been continued progress in identifying the components of the beef cattle production system which can be changed, in order to reduce methane emissions in particular. Intensive cattle finishing in feedlots has been shown to reduce GHGEs, compared to pasture-based systems (4.6 to 9.5 v. 10.2 to $12.4 \mathrm{~kg} \mathrm{CO}$-e/kg LW, respectively) (Wiedemann et al., 2016a and 2017a), and the application of lignite to feedlots reduces ammonia emissions by a further $30 \%$ (Sun et al., 2016). There are also options being researched for pasture-based systems, including carbon capture by use of permanent pastures (Soussana et al., 2010) and through planting of trees (Doran-Browne et al., 2018). Furthermore, the emissions per unit product can be decreased either by increasing livestock production efficiency or by targeting the source of the emissions, for example, by feeding or using novel technologies to reduce methane (Scollan et al., 2010). For example, in vitro ruminal testing of seaweed as a food source for cattle has been shown to reduce methane production by up to $50 \%$, depending on the amount administered (Kinley et al., 2016). Feeding seaweed to cattle to reduce methane emissions shows a lot of promise and obviously requires further investigation. Other feedstuffs are being investigated, and progress will be made in the future. Studies have also shown that methane emission is heritable and thus genetic selection can be used to reduce methane emissions from cattle production (Pickering et al., 2015).

\section{Summary and conclusions}

Consumer demand for cellular meat production derives from concerns over environment, animal welfare, consumer and public health aspects of animal production, use of antibiotics in the animal industries and food security.

As a concept, it has been suggested that cultured meat overcomes some of the ethical problems of livestock production but has also been criticised as a problematically technocentric, profit-motivated approach which will be dominated by large corporations (Lynch and Pierrehumbert, 2019).

The present limitations to cellular meat production include the identification of pluripotent cell lines in mammals, availability of cost-effective bovine-serum-free growth medium for cell proliferation and maturation, scaffold materials for cell growth, scaling-up to an industrial level and at what stage mixing of myo-, adipo- and fibrocytes can occur. In addition, consumer perceptions that cell-based meat production will result in improvements to animal welfare and the environment have been challenged, with the outcome needing to wait until cell-based meat is close to a commercial reality. Challenges for cell-based meat products include the simulation of nutritional attributes, texture, flavour and mouthfeel in animal-derived meat products. There is some question over whether consumers will accept the technology, but likely there will be acceptance of cell-based meat products in particular market segments. Currently, the cost of growth media, industry scale-up of specific components of the cell culture process, intellectual property sharing issues and regulatory hurdles mean that it will likely require take an extended period for cellular meat to be consistently available in high-end restaurants and even longer to be available for the mass market (Waughray, 2018).

Cellular meat production will likely be more efficient in utilising agricultural feedstocks than traditional forms of meat production as it may substitute industrial processes for the internal biological work done by animal physiology (Mattick et al., 2015a). Alternatively, maybe the upscaling and costs of production and technology development will not be sufficient for the price to drop substantially, and this high-tech food will remain at best an exclusive gastronomic, molecular cuisine (Banis, 2018).

The plant-based meat analogues are very well developed, with products such as the Impossible ${ }^{\mathrm{TM}}$ Burger and other products already available. These developments may make the development of cellular meat products obsolete (Banis, 2018). But the challenges remain of mimicking not only the flavour, shape and structure of real meat, but also the required changes in regulation and labelling.

\section{Acknowledgements}

The author acknowledges advice and assistance with the manuscript content from Dr. Jeremy Cottrell and Dr. Natalie Doran-Browne at Melbourne University, Prof. Peter Purslow at Universidad Nacional del Cetro de la Provincia de Buenos Aires in Argentina and Prof. Paul Mozdziak at North Carolina State University.

(1) R.D. Warner 0000-0001-5313-8773

\section{Declaration of interest}

The author declares no competing interests.

\section{Ethics statement}

Not applicable.

\section{Software and data repository sources}

None of the data were deposited in an official repository.

\section{References}

Aaslyng MD and Barton-Gade PA 2001. Low stress pre-slaughter handling: effect of lairage time on the meat quality of pork. Meat Science 57, 87-92.

Arihara K 2006. Strategies for designing novel functional meat products. Meat Science 74, 219-229. 
Banis D 2018. How Israel became the most promising land for clean meat. Retrieved on 18 July 2019 from https://www.forbes.com/sites/davidebanis/2018/10/17/howisrael-became-the-most-promising-land-for-clean-meat\#699752f751 cb

Bhat ZF, Kumar S and Bhat HF 2017. In vitro meat: a future animal-free harvest. Critical Reviews in Food Science and Nutrition 57, 782-789.

Bhat ZF, Kumar S and Fayaz H 2015. In vitro meat production: challenges and benefits over conventional meat production. Journal of Integrative Agriculture $14,241-248$.

Bhat ZF, Morton JD, Mason SL, Bekhit AE-DA and Bhat HF 2019. Technological, regulatory, and ethical aspects of in vitro meat: a future slaughter-free harvest. Comprehensive Reviews in Food Science and Food Safety 18, 1192-1208.

Blokhuis HJ, Veissier I, Miele M and Jones B 2010. The Welfare Quality ${ }^{\circledR}$ project and beyond: safeguarding farm animal well-being. Acta Agriculturae Scandinavica, Section A - Animal Science 60, 129-140.

Boffey D 2019. 'Veggie discs' to replace veggie burgers in EU crackdown on food labels. Retrieved on 18 July 2019 from https://www.theguardian.com/food/2019/ apr/04/eu-to-ban-non-meat-product-labels-veggie-burgers-and-vegan-steaks.

Bonny SPF, Gardner GE, Pethick DW and Hocquette J-F 2015. What is artificial meat and what does it mean for the future of the meat industry? Journal of Integrative Agriculture 14, 255-263.

Bonny SPF, Gardner GE, Pethick DW and Hocquette J-F 2017. Artificial meat and the future of the meat industry. Animal Production Science 57, 2216-2223.

Bryant $\mathrm{CJ}$ and Barnett JC 2019. What's in a name? Consumer perceptions of in vitro meat under different names. Appetite 137, 104-113.

Buller $\mathrm{H}$, Blokhuis $\mathrm{H}$, Jensen $\mathrm{P}$ and Keeling L 2018. Towards farm animal welfare and sustainability. Animals 8,81 .

Burton NM, Vierck Jf, Krabbenhoft L, Bryne K and Dodson MV 2000. Methods for animal satellite cell culture under a variety of conditions. Methods in Cell Science 22, 51-61.

Carlsson F, Frykblom P and Lagerkvist CJ 2007. Consumer willingness to pay for farm animal welfare: mobile abattoirs versus transportation to slaughter. European Review of Agricultural Economics 34, 321-344.

Cederberg C, Henriksson M and Berglund M 2013. An LCA researcher's wish listdata and emission models needed to improve LCA studies of animal production. Animal 7, 212-219.

Cliceri D, Spinelli S, Dinnella C, Prescott J and Monteleone E 2018. The influence of psychological traits, beliefs and taste responsiveness on implicit attitudes toward plant- and animal-based dishes among vegetarians, flexitarians and omnivores. Food Quality and Preference 68, 276-291.

Cornish A, Raubenheimer D and McGreevy P 2016. What we know about the public's level of concern for farm animal welfare in food production in developed countries. Animals 6,74

Crosson P, Shalloo L, O'Brien D, Lanigan GJ, Foley PA, Boland TM and Kenny DA 2011. A review of whole farm systems models of greenhouse gas emissions from beef and dairy cattle production systems. Animal Feed Science and Technology 166-167, 29-45.

Daly HE 1990. Toward some operational principles of sustainable development. Ecological Economics 2, 1-6.

Datar I and Betti M 2010. Possibilities for an in vitro meat production system. Innovative Food Science \& Emerging Technologies 11, 13-22.

Doran-Browne N, Wootton M, Taylor C and Eckard R 2018. Offsets required to reduce the carbon balance of sheep and beef farms through carbon sequestration in trees and soils. Animal Production Science 58, 1648-1655.

Edwards LN, Grandin T, Engle TE, Ritter MJ, Sosnicki AA, Carlson BA and Anderson DB 2010. The effects of pre-slaughter pig management from the farm to the processing plant on pork quality. Meat Science 86, 938-944.

Eriksen MS, Rødbotten R, Grøndahl AM, Friestad M, Andersen IL and Mejdell CM 2013. Mobile abattoir versus conventional slaughterhouse - impact on stress parameters and meat quality characteristics in Norwegian lambs. Applied Animal Behaviour Science 149, 21-29.

FAO 2011. Global food losses and food waste - extent, causes and prevention. Retrieved on 18 July 2019 from https://www.fao.org/3/mb060e/mb060e00.htm. FAO 2012. World agriculture towards 2030/2050: the 2012 revision. Retrieved on 18 July 2019 from http://www.fao.org/docrep/016/ap106e/ap106e.pdf.

FAO 2018. OECD-FAO Agricultural outlook 2018-2027 - Meat. Retrieved on 18 July 2019 from https://www.agri-outlook.org/commodities/AgriculturalOutlook-2018-Meat.pdf.
Farouk MM 2013. Advances in the industrial production of halal and kosher red meat. Meat Science 95, 805-820.

Farouk MM, Pufpaff KM and Amir M 2016. Industrial halal meat production and animal welfare: a review. Meat Science 120, 60-70.

Ferguson DM and Warner RD 2008. Have we underestimated the impact of preslaughter stress on meat quality in ruminants? Meat Science 80, 12-19.

Food-Standards-Code-Australia 2011. Hormonal growth promotants in beef In FSANZ, Sydney, Australia.

Frank D, Ball AJ, Hughes JM, Krishnamurthy R, Piyasiri U, Stark JL, Watkins PE and Warner R 2016. Sensory and objective flavor characteristics of Australian marbled beef: the influence of intramuscular fat, feed and breed. Journal of Agricultural and Food Chemistry 64, 4299-4311.

Gatti M 2019. I'm honestly fed up with all the bad news so $i$ illustrated the best news of 2018 (and recent years) \#49. Retrieved on 18 July 2019 from https:// www.boredpanda.com/illustration-good-positive-news-2018-mauro-gatti/?utm source=google\&utm_medium=organic\&utm_campaign=organic.

Grandin T 1997. Assessment of stress during handling and transport. Journal of Animal Science 75, 249-257.

Grandin T 1998. Handling and welfare of livestock in slaughter plants. In Livestock Handling and transport (ed. T Grandin), pp. 289-311. CAB International, Oxon, UK.

Grand-View-Research 2018. Meat substitutes market size, share \& trends analysis report by product (Tofu, Seitan, Tempeh, Quorn), by raw material (soy-based, wheat-based, mycoprotein), by region, and segment forecasts, 2012-2022. Retrieved on 18 July 2019 from https://www.grandviewresearch.com/industryanalysis/meat-substitutes-market

Gussow JD and Clancy KL 1986. Dietary guidelines for sustainability. Journal of Nutrition Education 18, 1-5.

Hoang YTH and Vu ATL 2016. Sodium benzoate and potassium sorbate in processed meat products collected in Ho Chi Minh City, Vietnam. International Journal on Advanced Science, Engineering and Information Technology 6, 477-482.

Hocquette A, Lambert C, Sinquin C, Peterolff L, Wagner Z, Bonny SPF, Lebert A and Hocquette J-F 2015. Educated consumers don't believe artificial meat is the solution to the problems with the meat industry. Journal of Integrative Agriculture 14, 273-284.

Hocquette J-F 2015. Is it possible to save the environment and satisfy consumers with artificial meat? Journal of Integrative Agriculture 14, 206-207.

Hocquette J-F 2016. Is in vitro meat the solution for the future? Meat Science 120, 167-176.

Hocquette JF and Chatellier V 2011. Prospects for the European beef sector over the next 30 years. Animal Frontiers 1, 20-28.

Hopkins PD 2015. Cultured meat in western media: the disproportionate coverage of vegetarian reactions, demographic realities, and implications for cultured meat marketing. Journal of Integrative Agriculture 14, 264-272.

Jochems CEA, van der Valk JBF, Stafleu FR and Baumans V 2002. The use of fetal bovine serum: ethical or scientific problem? Alternatives to Laboratory Animals 30, 219-227.

Jones AD, Hoey L, Blesh J, Miller L, Green A and Shapiro LF 2016. A systematic review of the measurement of sustainable diets. Advances in Nutrition 7 , 641-664.

Jorquera-Chavez M, Fuentes S, Dunshea FR, Jongman EC and Warner RD 2019. Computer vision and remote sensing to assess physiological responses of cattle to pre-slaughter stress, and its impact on beef quality: a review. Meat Science 156, 11-22.

Kadim IT, Mahgoub O, Baqir S, Faye B and Purchas R 2015. Cultured meat from muscle stem cells: a review of challenges and prospects. Journal of Integrative Agriculture 14, 222-233.

Kinley RD, de Nys R, Vucko MJ, Machado L and Tomkins NW 2016. The red macroalgae Asparagopsis taxiformis is a potent natural antimethanogenic that reduces methane production during in vitro fermentation with rumen fluid. Animal Production Science 56, 282-289.

Koohmaraie M, Whipple G, Kretchmar DH, Crouse JD and Mersmann HJ 1991. Postmortem proteolysis in longissimus muscle from beef, lamb, and pork carcasses. Journal of Animal Science 69, 617-624.

Kosnik PE, Dennis RG and Vandenburgh $H$ 2003. Tissue engineering skeletal muscle. In Functional tissue engineering (eds. F Guilak, DL Butler and SA Goldstein), pp. 377-392. Springer-Verlag, New York, NY, USA. 
Langelaan MLP, Boonen KJM, Polak RB, Baaijens FPT, Post MJ and van der Schaft DWJ 2010. Meet the new meat: tissue engineered skeletal muscle. Trends in Food Science \& Technology 21, 59-66.

Lipinski B, Hanson R, Lomax J, kitinoja L, Waite R and Searchinger T 2013. Reducing food loss and waste - working paper. In Working Paper, Installment 2 of Creating a Sustainable Food Future. World Resources Institute, Washington, DC, USA. Available online at https://www. worldresourcesreport.org.

Lynch J and Pierrehumbert R 2019. Climate impacts of cultured meat and beef cattle. Frontiers in Sustainable Food Systems 3, doi: 10.3389/fsufs.2019.00005.

MacLeod M, Gerber P, Mottet A, Tempio G, Falcucci A, Opio C, Vellinga T, Henderson B and Steinfeld H 2013. Greenhouse gas emissions from pig and chicken supply chains. A global life cycle assessment. Food and Agriculture Organization of the United Nations (FAO), Rome, Italy.

Mann NJ 2018. A brief history of meat in the human diet and current health implications. Meat Science 144, 169-179.

Mattick CS, Landis AE and Allenby BR 2015a. A case for systemic environmental analysis of cultured meat. Journal of Integrative Agriculture 14, 249-254.

Mattick CS, Landis AE, Allenby BR and Genovese NJ 2015c. Anticipatory life cycle analysis of in vitro biomass cultivation for cultured meat production in the United States. Environmental Science \& Technology 49, 11941-11949.

Mattick CS, Wetmore JM and Allenby BR 2015b. An anticipatory social assessment of factory-grown meat. IEEE Technology and Society Magazine 34, 56-64.

McAuliffe GA, Takahashi T and Lee MRF 2018. Framework for life cycle assessment of livestock production systems to account for the nutritional quality of final products. Food and Energy Security 7, e00143.

Moritz MSM, Verbruggen SEL and Post MJ 2015. Alternatives for large-scale production of cultured beef: a review. Journal of Integrative Agriculture 14, 208-216.

Mouly V, Aamiri A, Bigot A, Cooper RN, Di Donna S, Furling D, Gidaro T, Jacquemin V, Mamchaoui K, Negroni E, Périé S, Renault V, Silva-Barbosa SD and Butler-Browne GS 2005. The mitotic clock in skeletal muscle regeneration, disease and cell mediated gene therapy. Acta Physiologica Scandinavica 184, 3-15.

Nelson ME, Hamm MW, Hu FB, Abrams SA and Griffin TS 2016. Alignment of healthy dietary patterns and environmental sustainability: a systematic review. Advances in Nutrition 7, 1005-1025.

Orzechowski A 2015. Artificial meat? Feasible approach based on the experience from cell culture studies. Journal of Integrative Agriculture 14, 217-221.

Phelan K and May KM 2015. Basic techniques in mammalian cell tissue culture. Current Protocols in Cell Biology 66, 1.1.1-1.1.22.

Piazza J, Ruby MB, Loughnan S, Luong M, Kulik J, Watkins HM and Seigerman M 2015. Rationalizing meat consumption. The 4Ns. Appetite 91, 114-128.

Pickering NK, Oddy VH, Basarab J, Cammack K, Hayes B, Hegarty RS, Lassen J, McEwan JC, Miller S, Pinares-Patiño CS and de Haas Y 2015. Animal board invited review: genetic possibilities to reduce enteric methane emissions from ruminants. Animal 9, 1431-1440.

Piper K 2019. The lab-grown meat industry just got the regulatory oversight it's been begging for. In Vox. Retrieved on 18 July 2019 from https://www.vox.com/ future-perfect/2019/3/9/18255806/fda-usda-lab-grown-meat-cell-based-veganvegetarian.

Post M and Hocquette JF 2017. New sources of animal proteins: cultured meat. In Meat quality aspects: from genes to ethics (ed. P Purslow), pp. 425-441. Woodhead Publishing - Elsevier, Duxford, UK.

Post MJ 2012. Cultured meat from stem cells: challenges and prospects. Meat Science 92, 297-301.

Purslow PP, Oiseth S, Hughes J and Warner RD 2016. The structural basis of cooking loss in beef: variations with temperature and ageing. Food Research International 89, 731-748.

Ranganathan J, Waite R, Searcchinger T and Hanson C 2018. How to Sustainably Feed 10 Billion People by 2050, in 21 Charts. World Research Institute, Washington DC, USA. Retrieved on August 82019 from https://www.wri.org/ blog/2018/12/how-sustainably-feed-10-billion-people-2050-21-charts.

Renzini A, Benedetti A, Bouché M, Silvestroni L, Adamo S and Moresi V 2018. Culture conditions influence satellite cell activation and survival of single myofibers. European Journal of Translational Myology 28, 167-174.

Ritchie $\mathrm{H}$ and Roser M 2017. Meat and seafood production \& consumption. Retrieved on 18 July 2019 from https://ourworldindata.org/meat-and-seafoodproduction-consumption.
Rollins B and Rumley R 2019. The Regulation of 'Cell-Cultured Meat'. Retrieved on 18 July 2019 from https://nationalaglawcenter.org/wp-content/uploads/ assets/articles/rollins-rumley-Cell-cultured-meat.pdf.

Sala S, Anton A, McLaren SJ, Notarnicola B, Saouter E and Sonesson U 2017. In quest of reducing the environmental impacts of food production and consumption. Journal of Cleaner Production 140, 387-398.

Sanders ER 2012. Aseptic laboratory techniques: plating methods, JoVE, e3064. Retrieved on 18 July 2019 from https://www.jove.com/video/3064.

Scollan ND, Greenwood PL, Newbold CJ, Ruiz DRY, Shingfield KJ, Wallace RJ and Hocquette JF 2010. Future research priorities for animal production in a changing world. Animal Production Science 51, 1-5.

Smetana S, Mathys A, Knoch A and Heinz V 2015. Meat alternatives: life cycle assessment of most known meat substitutes. International Journal of Life Cycle Assessment 20, 1254.

Soussana JF, Tallec T and Blanfort V 2010. Mitigating the greenhouse gas balance of ruminant production systems through carbon sequestration in grasslands. Animal 4, 334-350.

Specht EA, Welch DR, Rees Clayton EM and Lagally CD 2018. Opportunities for applying biomedical production and manufacturing methods to the development of the clean meat industry. Biochemical Engineering Journal 132, 161-168. Stephens N, Di Silvio L, Dunsford I, Ellis M, Glencross A and Sexton A 2018. Bringing cultured meat to market: technical, socio-political, and regulatory challenges in cellular agriculture. Trends in Food Science \& Technology 78, 155-166. Stephens N, Sexton AE and Driessen C 2019. Making sense of making meat: key moments in the first 20 years of tissue engineering muscle to make food. Frontiers in Sustainable Food Systems 3, doi: 10.3389/fsufs.2019.00045.

Sun J, Bai M, Shen J, Griffith DWT, Denmead OT, Hill J, Lam SK, Mosier AR and Chen D 2016. Effects of lignite application on ammonia and nitrous oxide emissions from cattle pens. Science of the Total Environment 565, 148-154. Tatsumi R, Sheehan SM, Iwasaki H, Hattori A and Allen RE 2001. Mechanical stretch induces activation of skeletal muscle satellite cells in vitro. Experimental Cell Research 267, 107-114.

Toldra F, Aristoy MC, Mora L and Reig M 2012. Innovations in value-addition of edible meat by-products. Meat Science 92, 290-296.

Toldrá F, Mora L and Reig M 2016. New insights into meat by-product utilization. Meat Science 120, 54-59.

Tuomisto HL and Teixeira de Mattos MJ 2011. Environmental impacts of cultured meat production. Environmental Science \& Technology 45, 6117-6123.

van der Weele C, Feindt P, Jan van $\operatorname{der}$ Goot A, van Mierlo B and van Boekel M 2019. Meat alternatives: an integrative comparison. Trends in Food Science \& Technology 88, 505-512.

Van Der Weele C and Tramper J 2014. Cultured meat: every village its own factory. Trends in Biotechnology 32, 294-296.

Van Eelen WF 2007. Industrial production of meat using cell culture methods. US Patent 7,270,829 B2.

Vandenburgh HH and Karlisch P 1989. Longitudinal growth of skeletal myotubes in vitro in a new horizontal mechanical cell stimulator. In Vitro Cellular and Developmental Biology 25, 607-616.

Verbeke W, Sans P and Van Loo EJ 2015. Challenges and prospects for consumer acceptance of cultured meat. Journal of Integrative Agriculture 14, 285-294.

Voisinet BD, Grandin T, O'Connor SF, Tatum JD and Deesing MJ 1997. Bos indicus-cross feedlot cattle with excitable temperaments have tougher meat and a higher incidence of borderline dark cutters. Meat Science 46 , 367-377.

Warner RD, Ferguson DM, Cottrell JJ and Knee BW 2007. Acute stress induced by the preslaughter use of electric prodders causes tougher beef meat. Australian Journal of Experimental Agriculture 47, 782-788.

Warner RD, Greenwood PL, Pethick DW and Ferguson DM 2010. Genetic and environmental effects on meat quality. Meat Science 86, 171-183.

Watkins PJ, Frank D, Singh TK, Young OA and Warner RD 2013. Sheepmeat flavor and the effect of different feeding systems: a review. Journal of Agricultural and Food Chemistry 61, 3561-3579.

Waughray D 2018. Meat: the future. Time for a protein portfolio to meet tomorrows demand - A White Paper. Retrieved on 18 July 2019 from https://www3.weforum. org/docs/White_Paper_Meat_the_Future_Time_Protein_Portfolio_Meet_

Tomorrow_Demand_report_2018.pdf. 


\section{Warner}

WHO 2008. Conclusions of a WHO technical consultation on folate and vitamin B12 deficiencies. Food and Nutrition Bulletin 29, S238-S244.

Wiedemann S, Davis R, McGahan E, Murphy C and Redding M 2017a. Resource use and greenhouse gas emissions from grain-finishing beef cattle in seven Australian feedlots: a life cycle assessment. Animal Production Science 57, 1149-1162.

Wiedemann SG, McGahan EJ and Murphy CM 2017b. Resource use and environmental impacts from Australian chicken meat production. Journal of Cleaner Production 140, 675-684.

Wiedemann SG, McGahan EJ and Murphy CM 2018. Environmental impacts and resource use from Australian pork production determined using life cycle assessment. 2. Energy, water and land occupation. Animal Production Science 58, 1153-1163.
Wiedemann S, McGahan E, Murphy C and Yan M 2016a. Resource use and environmental impacts from beef production in eastern Australia investigated using life cycle assessment. Animal Production Science 56, 882-894.

Wiedemann SG, Yan M-J and Murphy CM 2016b. Resource use and environmental impacts from Australian export lamb production: a life cycle assessment. Animal Production Science 56, 1070-1080.

Willett W, Rockström J, Loken B, Springmann M, Lang T, Vermeulen S, Garnett T, Tilman D, DeClerck F, Wood A, Jonell M, Clark M, Gordon LJ, Fanzo J, Hawkes C, Zurayk R, Rivera JA, De Vries W, Majele Sibanda L, Afshin A, Chaudhary A, Herrero M, Agustina R, Branca F, Lartey A, Fan S, Crona B, Fox E, Bignet V, Troell M, Lindahl T, Singh S, Cornell SE, Srinath Reddy K, Narain S, Nishtar S and Murray CJL 2019. Food in the anthropocene: the EAT-Lancet Commission on healthy diets from sustainable food systems. The Lancet 393, 447-492. 